\title{
The mediating role of values in the relationship between religion and entrepreneurship
}

\author{
Cornelius A. Rietveld (D) B Brigitte Hoogendoorn
}

Accepted: 11 January 2021 / Published online: 5 April 2021

(C) The Author(s) 2021

\begin{abstract}
An emerging stream of literature argues that values entail a prime channel through which belonging to a religion and entrepreneurship are related. In this study, we introduce Schwartz's theory of basic human values to theorize on the role of values in the reciprocal relationship between belonging to a religion and entrepreneurship. Based on the motivational goal of each value, we argue that the value priorities of people belonging to a religion are opposite to these of entrepreneurs. We also go beyond earlier studies highlighting values as a prominent channel through which religion and entrepreneurship are connected by providing empirical evidence about the extent to which values mediate this relationship. By drawing on data from eight biennial survey waves (2002-2016) of the European Social Survey (32 countries), we show that individuals who belong to a religion prioritize values related to conservation higher than values related to openness to change, whereas the opposite is true for entrepreneurs. This contrast in value priorities cushions the relationship between belonging to a religion and entrepreneurship. However, both those belonging to a religion and
\end{abstract}

C. A. Rietveld · B. Hoogendoorn

Erasmus School of Economics, Erasmus University Rotterdam, Rotterdam, the Netherlands

\section{A. Rietveld $(\square)$}

Department of Applied Economics, Erasmus School of Economics, Erasmus University Rotterdam, P.O. Box 1738, 3000

DRRotterdam, the Netherlands

e-mail: nrietveld@ese.eur.nl entrepreneurs prioritize values related to self-transcendence over those related to self-enhancement. These relationships are fairly constant across the major religions in Europe, but do depend on how actively people engage in a religion and the type of entrepreneurship.

Plain English Summary New evidence about how values can explain the relationship between belonging to a religion and being an entrepreneur. For many people, religion provides the moral codes by which they live and herewith it shapes individual decision-making including the choice for certain occupations. However, religions do not prescribe occupational choices directly but shape these choices indirectly. A prominent role for values in the relationship between belonging to a religion and entrepreneurship is widely acknowledged theoretically, but hardly tested empirically. In this study, we use Schwartz' theory of basic human values to test this relationship and show that the value priorities of individuals belonging to a religion are opposite to those of entrepreneurs. Individuals who belong to a religion prioritize values related to conserving the social order higher than values related to openness to change and novelty, whereas the opposite is true for entrepreneurs. This contrast in value priorities weakens the relationship between belonging to a religion and entrepreneurship. Our findings are fairly constant across the major religions in Europe, but do depend on how actively people engage in a religion and the type of entrepreneurship. With a rapidly changing number of individuals adhering to a religion and increasing religious diversity in many European countries, our study is of practical importance 
by showing how these trends may have an impact on a country's entrepreneurship rate.

Keywords Religion · Entrepreneurship · Selfemployment $\cdot$ Values

JEL classifications A13 $\cdot$ L26 $\cdot$ Z12

\section{Introduction}

"By providing a sacred basis for prevailing norms and social structure, established religions encourage believers to accept the social order and discourage questioning and innovation" (Schwartz \& Huismans, 1995, p. 92).

"The typical entrepreneur is more self-centered than other types, because he relies less than they do on tradition and connection and because his characteristic task...consists precisely in breaking up old, and creating new, tradition" (Schumpeter, 1934, p. 91).

Globally, more than eight in ten people belong to a religious group. Europeans are generally less religious than people in other parts of the world, but still $45 \%$ of them declare that religion is somewhat or even very important in their lives (Pew Research Center, 2018). A growing body of literature has begun to explore how adherence to a religion influences the choice of entrepreneurship (Dodd \& Seaman, 1998; Audretsch, Bönte \& Tamvada, 2013; Rietveld \& Van Burg, 2014) because, beyond the consequences for individual persons, entrepreneurship impacts society at large through job creation (Van Praag \& Versloot, 2007; De Wit \& De Kok, 2014) and the stimulation of competitiveness and economic growth (Koellinger \& Thurik, 2012). Earlier studies argued that values concern a prominent channel through which religion and entrepreneurship are connected (Balog, Baker \& Walker, 2014; Dana, 2009; Audretsch et al., 2013; Hoogendoorn et al., 2016). However, empirical analysis of this channel has been scant which is surprising because it may increase our understanding of what is carrying the relationship between religion and entrepreneurship. The present study goes beyond earlier studies by proposing a unifying theory from comparative intercultural research to theorize and understand the role of values in the dynamic relationship between religion and entrepreneurship and by providing direct empirical evidence for it. The number of people adhering to a religion has been rapidly changing and diversifying in many societies in the last few decades, among others, because of secularization and immigration (Maoz \& Henderson, 2013; Norris \& Inglehart, 2004). As such, our study is of practical importance by showing how these trends may have an impact on a country's entrepreneurship rate.

Values constitute a person's normative framework and guide judgments and actions (Schwartz, 1992; Akerlof \& Kranton, 2000). Although many studies have shown the profound effect of religion on the value priorities of its adherents (Rockeach, 1969; Schwartz \& Huismans, 1995; Saroglou et al., 2004), other studies have made it clear that occupational experiences impact value priorities as well (Kohn and Schooler, 1982; Longest, Hitlin \& Vaisey, 2013). The contextual development and transient nature of value priorities presses the need to address the reciprocal impact of values in the relationship between religion and entrepreneurship. In this study, we do so by analyzing the mediating role of values in the relationship between religion and entrepreneurship. For our purpose, we draw on the theory of basic human values (Schwartz, 1992, 2012), which discriminates across ten universal values present in all major cultures. These ten basic human values are organized along two bipolar dimensions: conservation versus openness to change and self-transcendence versus self-enhancement. The theory offers a cross-culturally stable hierarchical model for the content and structure of values (Roccas, 2005) and facilitates a systematic assessment of the role of values in the relationship between religion and entrepreneurship.

Using biennial data from the European Social Survey $\left(\right.$ ESS) ${ }^{1}$ collected between 2002 and 2016 (8 survey rounds), we show that individuals belonging to a religion or denomination prioritize values related to conservation higher than values related to openness to change. In contrast, entrepreneurs prioritize openness to change over conservation. However, both those belonging to a religion and entrepreneurs prioritize values related to self-transcendence over those related to selfenhancement. Further analyses show that value

\footnotetext{
$\overline{{ }^{1} \mathrm{http}: / / \text { www.europeansocialsurvey.org/. }}$
} 
priorities are relatively similar across the major religions in Europe but are to some extent dependent on how actively people engage in a religion. Hence, we predict and find that, from a value perspective, there is a tension between belonging to a religion and being an entrepreneur.

The contribution of our study to the literature is threefold. First, we provide a comprehensive review of the existing survey-based studies on the relationship between religion and entrepreneurship and show that this literature is in need of a unifying theory explaining the role of values in this relationship. ${ }^{2}$ Earlier studies have convincingly argued that values are among the most important channels through which religion and entrepreneurship are related (see also Block et al., 2019), but these are theoretically sparse and empirically erratic. Second, we provide this unifying framework by introducing Schwartz's theory of basic human values to theorize on the role of values in the reciprocal relationship between religion and entrepreneurship. By exploiting the content of values as motivational concepts and the structure among these values, this theory allows predicting how someone's value priorities may impact behavior in various domains of life including religion and work. Hence, by explicitly allowing for a possible reciprocal relationship between belonging to a religion and entrepreneurship, the use of Schwartz's theory of basic human values helps to go beyond earlier unidirectional argumentation about the impact of belonging to a religion on entrepreneurship (Carroll \& Mosakowski, 1987; Minns \& Rivov, 2005). Beyond the present study, Schwartz's theory may also offer a suitable framework to further investigate the impact of values on other phenomena related to entrepreneurship such as female and social entrepreneurship. Third, we go beyond earlier studies highlighting values as a prominent channel through which religion and entrepreneurship are connected by providing empirical evidence about the extent to which values explain this relationship. In doing so, we scrutinize heterogeneity across the major religions in Europe and

\footnotetext{
$\overline{2}$ Our review concerns studies including an empirical analysis of the relationship between religion and entrepreneurship (using surveybased data). For a recent bibliometric analysis of the literature about religion and entrepreneurship with a broader focus, see Block, Fisch, and Rehan (2019).
}

the extent to which individuals actively engage in their religion. We find that values do explain, to some extent, the relation between belonging to a religion and entrepreneurship. ${ }^{3}$ However, our results are somewhat surprising in a literature where Weber's theory about the Protestant work ethic is a dominant starting point for many because we find that contrasting value priorities suppress the relationship between belonging to a religion and entrepreneurship.

The remainder of this paper is organized as follows. Section 2 presents the existing literature, introduces the theory of basic human values, and synthesizes separate streams of literature to derive expectations. Section 3 presents the data and methodology used, and the empirical results are presented in Section 4. Finally, Section 5 discusses the findings, draws conclusions, and highlights possible directions for future research.

\section{Literature and theoretical background}

This section starts by reviewing the existing studies on the relationship between religion and entrepreneurship (Section 2.1) and the role of values in this relationship (Section 2.2). Next, the theory of basic human values is introduced (Section 2.3), and expectations are derived about the value priorities of individuals belonging to a religion and entrepreneurs (Section 2.4).

\subsection{Religion and entrepreneurship}

Belonging to a religion encompasses many aspects such as commitment to a particular religious group, holding particular religious beliefs, and participation in religious activities individually or as part of a congregation (Lehrer, 2004). In survey-based research, it is common to distinguish between active (strong) and passive (weak) belonging to a religion based on one's engagement in religious activities such as prayer and regular

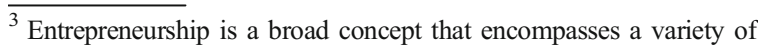
economic activities. Therefore, several empirical proxies for entrepreneurship are employed in the literature such as business ownership, nascent entrepreneurship, and self-employment(Parker, 2009). In this paper, we measure entrepreneurship with self-employment, the most commonly used proxy for entrepreneurship in the empirical entrepreneurship literature. Self-employment refers to the occupational notion of entrepreneurship and captures those operating a business on their own account and risk, independently without the control of supervisors (Wennekers \& Thurik, 1999).
} 
Table 1 Overview of empirical studies analyzing the relationship between religion and entrepreneurship (ordered according to year of publication)

\begin{tabular}{|c|c|c|c|c|c|}
\hline $\begin{array}{l}\text { Authors } \\
\text { (year) }\end{array}$ & Measures for religion & $\begin{array}{l}\text { Measures for } \\
\text { entrepreneurship }\end{array}$ & $\begin{array}{l}\text { Theoretical } \\
\text { framework }\end{array}$ & Sample (dataset) & Summary of results \\
\hline $\begin{array}{l}\text { Carroll and } \\
\text { Mosakow- } \\
\text { ski (1987) }\end{array}$ & $\begin{array}{l}\text { Self-identification as being } \\
\text { Protestant, Catholic, or } \\
\text { other }\end{array}$ & $\begin{array}{l}\text { Self-employment } \\
\text { in } \\
\text { manufacturing, } \\
\text { commerce, and } \\
\text { services }\end{array}$ & Weber thesis & $\begin{array}{l}2172 \text { West German } \\
\text { individuals } \\
\text { (West-German Life } \\
\text { History Study, } \\
\text { 1979-1984) }\end{array}$ & $\begin{array}{l}\text { Protestants are more likely } \\
\text { than others to move into } \\
\text { self-employment (includ- } \\
\text { ing family business) }\end{array}$ \\
\hline $\begin{array}{l}\text { Butler and } \\
\text { Herring } \\
\text { (1991) }\end{array}$ & $\begin{array}{l}\text { Self-identification as being } \\
\text { Jewish, Catholic, or other }\end{array}$ & Self-employment & $\begin{array}{l}\text { Middleman } \\
\text { theory; } \\
\text { ethnic } \\
\text { enclave } \\
\text { theory }\end{array}$ & $\begin{array}{l}7542 \text { American } \\
\text { individuals aged } 18 \\
\text { and above (General } \\
\text { Social Surveys, USA, } \\
\text { 1983-1987) }\end{array}$ & $\begin{array}{l}\text { Jews and non-Catholics are } \\
\text { more likely than others to } \\
\text { be self-employed }\end{array}$ \\
\hline $\begin{array}{l}\text { Dodd and } \\
\text { Seaman } \\
\text { (1999) }\end{array}$ & $\begin{array}{l}\text { (1) Belonging to any } \\
\text { particular religion, (2) at- } \\
\text { tendance of religious ser- } \\
\text { vices and meetings, (3) the } \\
\text { difference religion makes } \\
\text { to one's life, and (4) ad- } \\
\text { herence (i.e., combination } \\
\text { of } 1 \text { and 3) }\end{array}$ & $\begin{array}{l}\text { Self-employment, } \\
\text { (successful) } \\
\text { business own- } \\
\text { ership (growth } \\
\text { in profits and } \\
\text { workforce) }\end{array}$ & None & $\begin{array}{l}684 \text { economically active } \\
\text { British individuals } \\
\text { (British Household } \\
\text { Panel Study, } \\
\text { 1991/1992) }\end{array}$ & $\begin{array}{l}\text { No relationship between } \\
\text { religion and } \\
\text { self-employment or being } \\
\text { a (successful) business } \\
\text { owner }\end{array}$ \\
\hline $\begin{array}{l}\text { Minns and } \\
\text { Rivov } \\
\text { (2005) }\end{array}$ & $\begin{array}{l}\text { Self-identification as } \\
\text { belonging to a Catholic } \\
\text { church, a Protestant } \\
\text { church, or a Protestant } \\
\text { sect (e.g., Evangelical, } \\
\text { Pentecostal, or European } \\
\text { Free Church) }\end{array}$ & Self-employment & Weber thesis & $\begin{array}{l}\text { 19,904 economically } \\
\text { active Canadian males } \\
\text { aged 16-65 (Canadian } \\
\text { Census, 1901) }\end{array}$ & $\begin{array}{l}\text { Compared to Protestants, } \\
\text { Jews are more likely and } \\
\text { Catholics less likely to be } \\
\text { self-employed; no evi- } \\
\text { dence for those belonging } \\
\text { to Protestant sects }\end{array}$ \\
\hline $\begin{array}{l}\text { Nair and } \\
\text { Pandey } \\
(2006)\end{array}$ & $\begin{array}{l}\text { Belonging to Hindu or } \\
\text { non-Hindu minority reli- } \\
\text { gion }\end{array}$ & $\begin{array}{l}\text { Starting a business } \\
\text { and starting a } \\
\text { business that is } \\
\text { still running }\end{array}$ & None & $\begin{array}{l}80 \text { individuals who } \\
\text { started a business in } \\
\text { the manufacturing } \\
\text { industry in India } \\
\text { (Industralisation in } \\
\text { Kerela, 2002) }\end{array}$ & $\begin{array}{l}\text { No relationship between } \\
\text { religious affiliation and } \\
\text { starting a business or } \\
\text { succeeding }\end{array}$ \\
\hline $\begin{array}{l}\text { Carswell and } \\
\text { Rolland } \\
(2007)\end{array}$ & $\begin{array}{l}\text { Self-identification as being } \\
\text { Christian, Muslim, Hindu, } \\
\text { Jewish, Buddhist, or other }\end{array}$ & $\begin{array}{l}\text { Nascent or young } \\
\text { business owner }\end{array}$ & None & $\begin{array}{l}2000 \text { randomly selected } \\
\text { New Zealanders aged } \\
\text { 18-65 (Bartercard } \\
\text { New Zealand Global } \\
\text { Entrepreneurship } \\
\text { Monitor, 2002) }\end{array}$ & $\begin{array}{l}\text { Non-Christians are more } \\
\text { likely to be business } \\
\text { owners }\end{array}$ \\
\hline $\begin{array}{l}\text { De Noble } \\
\text { et al. } \\
\quad(2007)\end{array}$ & $\begin{array}{l}\text { Intrinsic religious orientation } \\
\text { and extrinsic religious } \\
\text { orientation }\end{array}$ & $\begin{array}{l}\text { Opinions and } \\
\text { personal } \\
\text { attitudes about } \\
\text { entrepreneur- } \\
\text { ship and } \\
\text { self-- } \\
\text { employment }\end{array}$ & Weber thesis & $\begin{array}{l}\text { Survey of } 141 \text { American } \\
\text { senior-level business } \\
\text { students interested in } \\
\text { an entrepreneurial ca- } \\
\text { reer }\end{array}$ & $\begin{array}{l}\text { Intrinsic religiosity is } \\
\text { positively related to } \\
\text { perceptions about and } \\
\text { actual self-employment; } \\
\text { extrinsic religiosity is } \\
\text { negatively related to actu- } \\
\text { al self-employment }\end{array}$ \\
\hline $\begin{array}{l}\text { Nunziata and } \\
\text { Rocco } \\
(2011)\end{array}$ & $\begin{array}{l}\text { Self-identification as } \\
\text { belonging to a Catholic } \\
\text { church or Protestant } \\
\text { church or being } \\
\text { non-religious; intensity of } \\
\text { adhesion to religion }\end{array}$ & $\begin{array}{l}\text { Self-employment } \\
\text { with and } \\
\text { without } \\
\text { employees }\end{array}$ & Weber thesis & $\begin{array}{c}78,889 \text { economically } \\
\text { active individuals } \\
\text { (ESS, 2002-2008) }\end{array}$ & $\begin{array}{l}\text { Protestants are more likely } \\
\text { than Catholics to be } \\
\text { self-employed; religious } \\
\text { denominations have a sig- } \\
\text { nificant impact on indi- } \\
\text { vidual choices when the } \\
\text { adhesion to religion is } \\
\text { strong }\end{array}$ \\
\hline
\end{tabular}


Table 1 (continued)

\begin{tabular}{|c|c|c|c|c|c|}
\hline $\begin{array}{l}\text { Authors } \\
\text { (year) }\end{array}$ & Measures for religion & $\begin{array}{l}\text { Measures for } \\
\text { entrepreneurship }\end{array}$ & $\begin{array}{l}\text { Theoretical } \\
\text { framework }\end{array}$ & Sample (dataset) & Summary of results \\
\hline $\begin{array}{l}\text { Audretsch } \\
\text { et al. } \\
\text { (2013) }\end{array}$ & $\begin{array}{l}\text { Self-identification as } \\
\text { belonging to Hinduism, } \\
\text { Islam, Christianity, } \\
\text { Sikhism, Jainism, or } \\
\text { Buddhism }\end{array}$ & Self-employment & $\begin{array}{l}\text { Institutional } \\
\text { theory } \\
\text { (norms and } \\
\text { cognition); } \\
\text { social } \\
\text { dominance } \\
\text { theory }\end{array}$ & $\begin{array}{l}\text { 82,436 economically } \\
\text { active Indian } \\
\text { individuals aged } \\
\text { 15-70 (National Sam- } \\
\text { ple Survey Organiza- } \\
\text { tion of India, 2004) }\end{array}$ & $\begin{array}{l}\text { Hinduism and Buddhism } \\
\text { restrict self-employment, } \\
\text { Islam and Jainism } \\
\text { encourage } \\
\text { self-employment } \\
\text { activities, and Christianity } \\
\text { not significantly associat- } \\
\text { ed with self-employment }\end{array}$ \\
\hline $\begin{array}{l}\text { Dougherty } \\
\text { et al. } \\
\text { (2013) }\end{array}$ & $\begin{array}{l}\text { Self-identification as } \\
\text { evangelical Protestant, } \\
\text { mainline Protestant, black } \\
\text { Protestant, Catholic, } \\
\text { other, or no religion; } \\
\text { personal beliefs about } \\
\text { God; religious service } \\
\text { attendance and prayer; } \\
\text { whether a respondent's } \\
\text { place of worship } \\
\text { encourages one to start a } \\
\text { business and to make a } \\
\text { profit in business }\end{array}$ & $\begin{array}{l}\text { Ever started or } \\
\text { currently trying } \\
\text { to start a new } \\
\text { business }\end{array}$ & None & $\begin{array}{l}1714 \text { random American } \\
\text { individuals aged over } \\
18 \text { (Baylor Religion } \\
\text { Survey, 2010) }\end{array}$ & $\begin{array}{l}\text { No relationship between } \\
\text { religious affiliation, } \\
\text { believing in God, or } \\
\text { attending religious } \\
\text { services and having ever } \\
\text { started or currently } \\
\text { starting a business; } \\
\text { however, those having } \\
\text { started or currently } \\
\text { starting a business see } \\
\text { God as more personal, } \\
\text { pray more frequently, and } \\
\text { are more likely to attend a } \\
\text { place of worship that } \\
\text { encourages business } \\
\text { activity }\end{array}$ \\
\hline $\begin{array}{l}\text { Hill, Perkins, } \\
\text { White } \\
\text { (2015) }\end{array}$ & $\begin{array}{l}\text { Self-identification as being } \\
\text { Christian or } \\
\text { non-Christian; having } \\
\text { strong religious beliefs }\end{array}$ & $\begin{array}{l}\text { Self-employment; } \\
\text { Preference for } \\
\text { self-- } \\
\text { employment }\end{array}$ & None & $\begin{array}{l}\text { 57,061 American } \\
\text { individuals aged } 18 \\
\text { and above (General } \\
\text { Social Science } \\
\text { Survey, USA) }\end{array}$ & $\begin{array}{l}\text { Non-Christians are more } \\
\text { likely to be self-employed } \\
\text { than Christians; Christians } \\
\text { are more likely to prefer } \\
\text { self-employment than } \\
\text { non-Christians; both con- } \\
\text { clusions hold when the } \\
\text { strength of religiosity is } \\
\text { taken into account }\end{array}$ \\
\hline $\begin{array}{r}\text { Wyrwich } \\
(2018)\end{array}$ & $\begin{array}{l}\text { Self-identification as } \\
\text { Protestant }\end{array}$ & $\begin{array}{l}\text { Planning to } \\
\text { become } \\
\text { self-employed } \\
\text { and entry into } \\
\text { self-- } \\
\text { employment }\end{array}$ & Weber thesis & $\begin{array}{l}\text { Approximately } 2900 \\
\text { East German } \\
\text { individuals (German } \\
\text { Socioeconomic Panel, } \\
\text { 1989-1990) }\end{array}$ & $\begin{array}{l}\text { Being a Protestant has a } \\
\text { positive influence on both } \\
\text { planning to become } \\
\text { self-employed and actual } \\
\text { entry into self-- } \\
\text { employment }\end{array}$ \\
\hline $\begin{array}{l}\text { Dougherty } \\
\text { et al. } \\
\text { (2019) }\end{array}$ & $\begin{array}{l}\text { Prosperity gospel beliefs } \\
\text { scale }\end{array}$ & $\begin{array}{l}\text { Ever started a } \\
\text { business or } \\
\text { organization }\end{array}$ & $\begin{array}{l}\text { Values theory } \\
\text { (Schwartz) }\end{array}$ & $\begin{array}{l}1022 \text { American full-time } \\
\text { employed individuals } \\
\text { aged } 18 \text { and above } \\
\text { (probability-based } \\
\text { web panel) }\end{array}$ & $\begin{array}{l}\text { No direct impact of } \\
\text { prosperity beliefs on } \\
\text { entrepreneurial attitudes } \\
\text { or action. Prosperity } \\
\text { beliefs moderate the } \\
\text { impact of values on the } \\
\text { likelihood of starting a } \\
\text { business }\end{array}$ \\
\hline
\end{tabular}

attendance at a place of worship (e.g., Office for National Statistics, 2009). Several studies have shown that belonging to a religion affects economic preferences such as risk aversion and trust (Shariff \& Norenzayan, 2007; Benjamin, Choi \& Fisher, 2016) and, consequently, economic decision-making and behavior 
(Iannaccone, 1998). An emerging stream of literature analyzes how belonging to a religion and entrepreneurship are related, with a bifurcation between studies focusing on the choice of entrepreneurship over wagework and studies analyzing the influence of religion on entrepreneurial decision-making(Balog et al., 2014; Dodd \& Gotsis, 2007; Kojana \& Mamabolo, 2020). The present study contributes to the first strand of the literature.

The main research question in this stream of studies, whether belonging to a particular religion or denomination affects one's choice of entrepreneurship, has been answered in many different ways. Table 1 provides an overview of the literature and shows that the various findings sometimes contradict each other. For example, some studies concluded that Protestants and Jews have a higher propensity to become an entrepreneur than Catholics (Carroll \& Mosakowski 1987; Butler \& Herring, 1991; Minns \& Rizov, 2005; Nunziata \& Rocco, 2011), while other studies do not find significant differences between entrepreneurs and wage workers with regard to religious affiliation or religious service attendance (Dodd \& Seaman, 1998; Carswell \& Rolland, 2007; Dougherty, Griebel, Neubert \& Park, 2013).

The harmonization of the earlier findings about the relationship between religion and entrepreneurship is not straightforward because they result from studies employing a range of measures for religion and entrepreneurship in samples originating from different countries. For example, while Protestants and Catholics are considered distinct denominations by some (Caroll \& Mosakowski, 1987; Nunziata \& Rocco, 2011), they are combined into Christianity by others (Hill et al., 2015; Audretsch et al., 2013) or further divided into smaller denominations such as Evangelical and European Free Church (Minns \& Rivov, 2005). In addition, a diversity of measures are used for assessing engagement in a religion such as the frequency of church attendance and prayer (Hill et al., 2015; Dougherty et al., 2013; Dodd \& Seaman, 1998), and various types of entrepreneurship are considered such as running a young or established business with or without employees (Dougherty et al., 2013; Nunziato \& Rocco, 2011).

What is most important in the context of this study is that all but one study (Dougherty et al., 2019) in Table 1 estimate a direct ("net") relationship between religion and entrepreneurship. However, religions do not prescribe occupational choices directly but shape these choices indirectly through its impact on values, social norms, networks, and attitudes (Audretsch et al., 2013; Hoogendoorn et al., 2016). The importance of these various mediating factors that together make up to the full relationship may vary over time and across different countries, making conclusions about the net relationship difficult to generalize. Therefore, to further develop this stream of the literature, an important step is to start analyzing specific channels through which religion and entrepreneurship are connected.

The three most prominent channels through which religion and entrepreneurship are thought to be linked are social capital (Balog et al., 2014; Hoogendoorn et al., 2016; Nunziata \& Rocco, 2011), normative, and cognitive institutions (Audretsch et al., 2013), and values (Audretsch et al., 2013; Dana, 2009; Dougherty et al., 2019; Hoogendoorn et al., 2016). There is a broad consensus that social capital positively affects entrepreneurship (Parker, 2009). Balog et al. (2014) and Hoogendoorn et al. (2016) put forward that religion, being an important source of social capital, is positively associated with entrepreneurial activity. Nunziata and Rocco (2011) add that belonging to a minority religion strengthens social capital formation, as social ties tend to be stronger in smaller communities. The institutional perspective on which Audretsch et al. (2013) draw to explain the relation between religion and entrepreneurship in India is closely related to the value channel with the normative institutional dimension defined as comprising social norms. When individuals are "living out their personal values" (Balog et al., 2014, p. 160), they do so in part because they adhere to the social norms that prevail in the social groups they belong to. Nevertheless, values have been highlighted as one of the most important channels through which religion and entrepreneurship are connected. Notably, the seminal work by Weber (1930) highlights that the Protestant work ethic, which played a role in the rise of the capitalist enterprise, is the result of a person's subscription to the values espoused by the Protestant faith (Tracey, 2012). Early Protestant thinkers, such as Luther and Calvin, conceptualized worldly work as vocation, in contrast with the Roman Catholic tradition with its emphasis on clerical work. Protestants were attracted to hard work and frugality to discern themselves as being elected and predestined and to fulfill their duty to serve others through their occupational efforts. Hence, the frequency of drawing on the famous Weber thesis in the literature about religion and entrepreneurship (see Table 1) also points to the need for a more in-depth analysis of this relationship on the level of values. 
While the role of values as a prominent channel through which religion and entrepreneurship are connected is widely acknowledged theoretically, empirically testing of this relationship is scant. One exception is the recent study by Dougherty et al. (2019) providing support for a moderating role of religious beliefs (i.e., prosperity beliefs) in the relationship between values and entrepreneurial attitudes and motivations. In this study, we investigate to what extent values mediate the relationship between religion and entrepreneurship.

2.2 Values and the relationship between religion and entrepreneurship

Values are the criteria or broad life goals guiding an individual's judgments, actions, and behaviors (Rokeach 1969; Parks-Leduc, Feldman, \& Bardi, 2015). They entail conceptions of the desirable, and, as such, they constitute human behavior (Schwartz, 1992; Arieli, Sagiv \& Roccas, 2019). Values pertain to desirable end states, guide behavior, transcend specific situations and - importantly - can be ordered by relative importance (Hitlin, 2003). Values are core elements of a person's sense of self, and individuals try to avoid behaviors that conflict with their values while undertaking actions that reinforce their sense of self. Hence, individuals may choose differently when confronted with apparently similar choices because of different value priorities.

Religion can be defined as "a particular set of beliefs, practices, and rituals that have been developed in community by people who share similar existential experiences of transcendent reality" (Hodge, 2003, p. 42). For many people, these religious beliefs, practices, and rituals are central to their everyday lives, as religion provides the moral codes by which they live (Geertz, 1993). Thus, religion and values are related in a sense that both guide an individual's judgments, actions and behaviors, and they are different in the sense that religion is an integrative entity combining not only values but also practices, rituals, emotions, and community (Saroglou et al., 2004). As such, cross-cultural empirical research does not support the existence of a universal religious value. That is, the motivational goals for religious values do not apply for most people or these goals are expressed through other values (Schwartz, 1992, 1994). In both cases, these findings suggest that religion and values are related but distinct concepts.
Nevertheless, many studies have shown that religion and values are intrinsically related in a complex manner (Saroglou et al., 2004). Through theological teachings or socialization, religions stress or temper the prominence of particular values such as respect for others (Rockeach, 1969; Roccas \& Schwartz, 1997). The more religiously committed a person is, the more likely he is to adopt the prevailing values of the religion he or she adheres to (Roccas, 2005). Also, individuals with specific value priorities may seek out specific religions that reinforce their value priorities (Schwartz \& Huismans, 1995). Thus, individual value differences may predispose people to adhere, believe in, or practice religion (Saroglou et al., 2004).

A range of studies confirms that the value priorities of religious individuals are indeed different from those of less or non-religious people (Rockeach, 1969; Schwartz and Huismans, 1995; Roccas and Schwartz, 1997; Roccas, 2005; Saroglou et al., 2004). For example, Rokeach (1969) reports that religious people consistently rank the values of forgiveness, salvation, and obedience relatively high, while ranking pleasure and independence relatively low. There is also evidence that the strength of these relationships depends on the extent of engagement in a religion. In some studies, behavioral measures such as the attendance of religious services and the frequency of prayer are stronger predictors of value priorities than self-identification with a religious denomination (Nunziata and Rocco, 2011; Longest et al., 2013; Guiso, Sapienza \& Zingales, 2006). However, contrary to the difference in value priorities between religious and non-religious people, the value priorities across different religious denominations show little variation and are notably similar (Schwartz \& Huismans, 1995; Saraglou et al., 2004). ${ }^{4}$

Another stream of studies links values with the choices and behavior of individuals in work settings (Arieli, Sagiv, Roccas, 2019). More specifically, it has been suggested that the value priorities of entrepreneurs differ from those of non-entrepreneurs(Beugelsdijk \& Noorderhaven, 2005; Noseleit, 2010). Independent thought, choosing one's own goals, exploring, and questioning prevailing practices are considered core

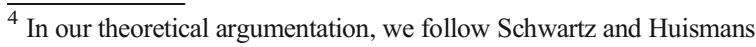
(1995) and Saroglou et al. (2004) by not taking into account the specific religion an individual belongs to. Still, in our empirical analyses, we allow for heterogeneity with respect to the specific religion or denomination an individual belongs to within the subsample of individuals belonging to a religion.
} 
Table 2 Overview of the four value groups and the ten basic human values with their motivational goals in Schwartz's theory of basic human values, as well as their associations with religion and entrepreneurship

\begin{tabular}{llll}
\hline Value group & $\begin{array}{l}\text { Associationwith } \\
\text { religion }\end{array}$ & $\begin{array}{l}\text { Association with } \\
\text { entrepreneurship }\end{array}$ & $\begin{array}{l}\text { Basic human } \\
\text { value }\end{array}$ \\
\hline
\end{tabular}

Bipolar dimension openness to change vs. conservation

\begin{tabular}{|c|c|c|c|c|}
\hline \multirow{3}{*}{$\begin{array}{l}\text { Openness to } \\
\text { change }\end{array}$} & \multirow[t]{3}{*}{-} & \multirow[t]{3}{*}{+} & Stimulation & Excitement, novelty, and challenge in life \\
\hline & & & Self-direction & $\begin{array}{l}\text { Independent thought and action-choosing, } \\
\text { creating, and exploring }\end{array}$ \\
\hline & & & Hedonism $^{\mathrm{a}}$ & Pleasure and sensuous gratification for oneself \\
\hline \multirow[t]{3}{*}{ Conservation } & \multirow[t]{3}{*}{+} & \multirow[t]{3}{*}{-} & Tradition & $\begin{array}{l}\text { Respect, commitment, and acceptance of the customs and } \\
\text { ideas that traditional culture or religion provides to the } \\
\text { self }\end{array}$ \\
\hline & & & Conformity & $\begin{array}{l}\text { Restraint of actions, inclinations, and impulses likely to } \\
\text { upset or harm others and violate social expectations or } \\
\text { norms }\end{array}$ \\
\hline & & & Security & $\begin{array}{l}\text { Safety, harmony, and stability of society, of relationships, } \\
\text { and of the self }\end{array}$ \\
\hline \multicolumn{5}{|c|}{ Bipolar dimension self-enhancement vs. self-transcendence } \\
\hline \multirow[t]{2}{*}{ Self-enhancement } & \multirow[t]{2}{*}{-} & \multirow[t]{2}{*}{+} & Power & $\begin{array}{l}\text { Social status and prestige, control or dominance over } \\
\text { people and resources }\end{array}$ \\
\hline & & & Achievement & $\begin{array}{l}\text { Personal success through demonstrating competence } \\
\text { according to social standards }\end{array}$ \\
\hline \multirow[t]{2}{*}{ Self-transcendence } & \multirow[t]{2}{*}{+} & \multirow[t]{2}{*}{-} & Universalism & $\begin{array}{l}\text { Understanding, appreciation, tolerance, and protection for } \\
\text { the welfare of all people and for nature }\end{array}$ \\
\hline & & & Benevolence & $\begin{array}{l}\text { Preservation and enhancement of the welfare of people } \\
\text { with whom one is in frequent personal contact }\end{array}$ \\
\hline
\end{tabular}

Sources: Schwartz (2001), Roccas (2005), Licht (2010), and Dougherty et al. (2019)

${ }^{a}$ Hedonism shares elements of openness to change and self-enhancement (see Fig. 1) but is usually contained under openness to change (see, e.g., Figure 2 in Schwartz (2012))

aspects of identifying and exploiting entrepreneurial opportunities and considered necessary virtues for and actions in entrepreneurship (Cliff, Jennings \& Greenwood, 2006; Shane \& Venkataramen, 2000). Licht $(2007,2010)$ even argues that openness to change, expressed as seeking novelty and challenges in life and being independent in thought, is the preeminent distinguishing characteristic of entrepreneurs. Relatedly, values and psychological traits are considered distinct but related components of personality, and both motivate individual behavior (McCrae \& Costa, 2008) with consistent correlation patterns (Parks-Leduc et al., 2015). Metaanalyses in this research area have also shown that those creating a business score particularly high on a need for achievement, self-efficacy, and conscientiousness (e.g., Rauch \& Frese, 2007).

Although values may drive people toward entrepreneurship, it has also been established that occupational experiences and work characteristics such as closeness of supervision, routinization, and task complexity affect value priorities (Longest et al., 2013; Kohn \& Schooler, 1982). Employment conditions are internalized so that those individuals who enjoy higher levels of autonomy in their job come to value self-direction, whereas individuals in jobs characterized by a lower level of autonomy prefer conformity. Occupational characteristics typically associated with entrepreneurship such as workplace autonomy and complexity of tasks (Hessels, Rietveld \& Van der Zwan, 2017) increase the importance people place on change-related values and achievement and decrease the importance of conservation values (Longest et al., 2013). Hence, religion, values, and entrepreneurship are related in a complex and reciprocal manner (Chaves, 2010). To shed further light on this complex relationship and the role of values, the literature is in need of a unifying value theory. 


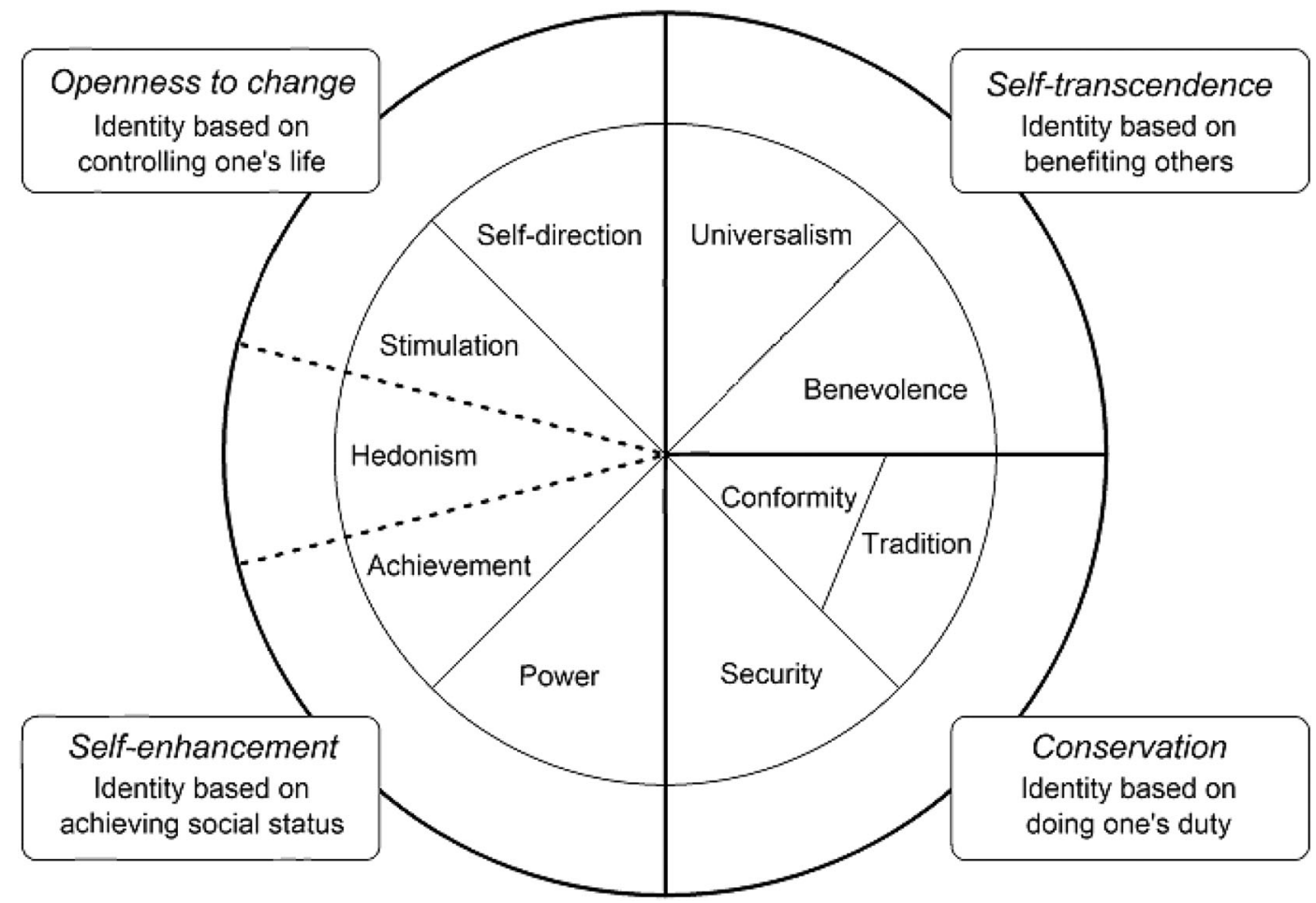

Fig. 1 The four value groups and the ten basic human values in Schwartz's theory of basic human values

\subsection{The theory of basic human values}

In this study, we draw on the theory of basic human values as developed by the social psychologist Schwartz $(1992,2012)$. The choice to take Schwartz's theory of basic human values as the theoretical backbone of the present study is motivated by (i) its provision of a clear structure of values allowing the analysis of value priorities and of the conflicts and compatibility between values (Roccas, 2005; Knafo, Roccas \& Sagic, 2011), (ii) its measurability on the individual level (compared to, for instance, Hofstede's country-level measurements of cultural values (Hofstede, Hofstede \& Minkov, 2010)), and (iii) its empirically validated cross-cultural stability (Longest et al., 2013; Schwartz, 2012).

Schwartz's theory provides propositions regarding the content of values and the structure or dynamic relationships among them. Based on cross-cultural research, he distinguishes ten motivationally distinct basic values that are organized in four value groups along two bipolar dimensions
(Table 2) $)^{5}$. The interconnectedness of Schwartz's values can be visualized as a circle (Fig. 1). The ten basic human values that are adjacent in the circle have overlapping motivational goals and are mutually supporting, whereas values on opposite sides of the circle have competing and opposing goals. For example, the pursuit of power is generally in accordance with seeking achievement but in conflict with striving for benevolence. This presence of value conflicts is even more evident from the bipolarity of the four value groups. The first dimension contrasts self-enhancement with self-

\footnotetext{
${ }_{5}^{5}$ Early, tentative versions of the theory of basic human values considered the possibility that spirituality may constitute an eleventh universal value with the motivational goal being meaning and inner harmony through the transcendence of everyday reality (Schwartz, 1992). The final version of the theory of basic human values does not include spirituality as a distinct basic value, because empirical evidence suggests that the hypothesized motivational goals of spirituality serve as guiding principles for only a subset of people and that these goals also find their expression already through other value types (Schwartz 1992, 1994). As such, spirituality does not constitute a universal basic human value, warranting the use of belonging to a religion and the ten basic human values from Schwartz's theory as related but distinct concepts in our study.
} 
transcendence and captures the conflict between a concern for the welfare and interests of others and the pursuit of one's own interest. The second dimension distinguishes openness to change from conservation and captures the conflict of independence and readiness for change with a desire to preserve the past and a resistance to change. The integrated circular structure allows for the generation of hypotheses about the relationship of value priorities with attitudes and behavior (Schwartz 1992, Schwartz \& Huismans, 1995).

Each value is linked with behavioral actions through its motivational goal (Schwartz, 1992; Roccas, 2005). The motivational goal for each value can be found in Table 2. For example, a person favoring security will motivate his actions towards the assurance of the safety, harmony and stability of society, relationships, and himself. However, a person favoring, for instance, stimulation will feel inspired and motivated in a situation that brings excitement and novelty to his life. Schwartz (1992) further reasons that the simultaneous pursuit of values from opposite sides of the circle gives rise to strong psychological and/or social conflict, and behaving in discordance with one's values will also result in feelings of stress and discomfort (Akerlof \& Kranton, 2000). Hence, behavioral actions can be explained by individual-specific value profiles in which the relative priority of values is of particular importance (Schwartz, 1992; Hitlin, 2003).

\subsection{Synthesis and derivation of expectations}

Our central question is whether values can explain the relationship between belonging to a religion and entrepreneurship. In terms of Schwartz's bipolar value dimensions, the value priorities of individuals belonging to a religion do not seem to correspond to values typically associated with entrepreneurship (Table 2; Hoogendoorn et al., 2016). Religions aim to preserve the social order and protect individuals against uncertainty (Schwartz \& Huismans, 1995; Roccas, 2005). This goal is achieved by commitment to the customs and ideas that religions provide and by being restrained in actions, inclinations, and impulses that are likely to upset or harm others and violate social expectations or norms. As a result, individuals belonging to a religion do not place high importance on seeking excitement, novelty, and independent thought, nor do they tend to favor intellectual or emotional openness to change. On the openness to change vs. conservation dimension, individuals belonging to a religion therefore prioritize values related to conservation over values related to openness to change(Saroglou et al., 2004). In contrast, independent thought, exploration, and questioning prevailing practices are the hallmarks of entrepreneurial behavior (Cliff, Jennings \& Greenwood, 2006; Shane $\&$ Venkataramen, 2000). For entrepreneurs, openness to change is more important than conservation. (Licht, 2007, 2010; Noseleit, 2010). In line with earlier findings, we expect entrepreneurs to prioritize openness to change over conservation, where we expect the opposite to hold for individuals belonging to a religion.

A similar value conflict between belonging to a religion and entrepreneurship can be found in Schwartz's second bipolar value dimension, self-enhancement vs. self-transcendence. Self-transcendence, thriving to benefit people with whom one is in frequent personal contact and protecting the welfare of all people, correlates with the spiritual teachings and practices of many religions stimulating pro-sociality and altruism. In contrast, self-enhancement emphasizes personal success and achievement, including a materialistic component, and opposes the same spiritual teachings (Schwartz \& Huismans, 1995; Roccas, 2005; Saroglou, Corneille \& Van Cappellen, 2009). The meta-analysis by Saroglou et al. (2004) provides empirical support that people belonging to a religion indeed generally prioritize self-transcendence over self-enhancement ${ }^{6}$. The drive for self-enhancement is expressed in terms of being very successful, having status and prestige, and entails wealth accumulation and non-pecuniary benefits, such as autonomy. Entrepreneurship success corresponds to the central goals of self-enhancement(Licht, 2007, 2010). Noseleit (2010) provides empirical support for the presumption that entrepreneurs generally prioritize selfenhancement over self-transcendence. Thus, while individuals belonging to a religion favor self-transcendence over self-enhancement, we expect the opposite to hold for entrepreneurs.

In sum, values pertain to broad life goals and provide directions for an individual's judgments and behaviors. As such, values are also expected to play a pivotal role in the relationship between belonging to a religion and entrepreneurship. Importantly, belonging to a religion and entrepreneurship affect and are affected by one's value priorities. Figure 2 visualizes the bidirectionality of these relationships. Notably, the direction of effects between belonging to a religion and values (the left part of Fig. 2) are congruent: Belonging to a religion 


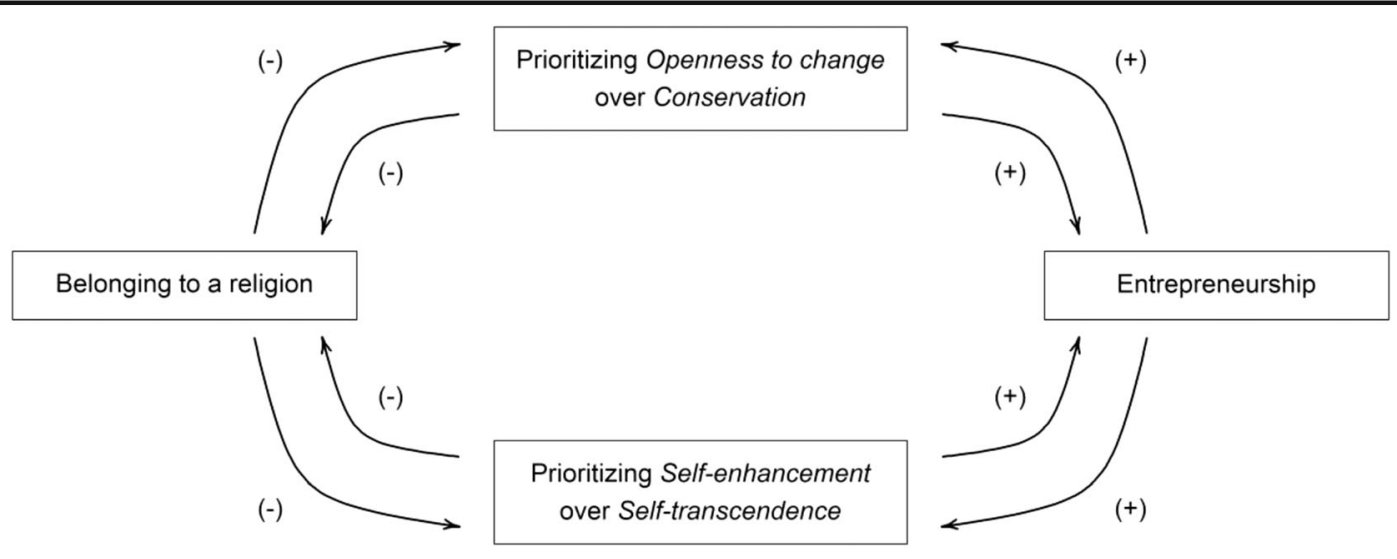

Fig. 2 The relationships between belonging to a religion, values, and entrepreneurship

negatively affects prioritizing openness to change over conservation and self-enhancement over self-transcendence, and having these value priorities makes it is less likely to become a member of a religion. The direction of effects between entrepreneurship and values (the right part of Fig. 2) is also congruent: Prioritizing openness to change over conservation and self-enhancement over self-transcendence makes it more likely that a person chooses entrepreneurship, and entrepreneurship reinforces these value priorities. These directional congruencies in the left and right parts of the model (Fig. 2) make it possible to formulate an expectation about how values explain the relationship between belonging to a religion and entrepreneurship. Those prioritizing openness to change over conservation will be relatively less likely to belong to a religion but more likely to be an entrepreneur. The same is true for those favoring selfenhancement over self-transcendence. As a result, both the effect of belonging to a religion on entrepreneurship through values as well as the effect of entrepreneurship on belonging to a religion through values are expected to be negative. The effects in both directions are negative and thus do not cancel out each other. Therefore, we hypothesize that the combined (bidirectional) effect of values in the relationship between belonging to a religion and entrepreneurship is negative. Hence, we expect that values weaken the relationship between belonging to a religion and entrepreneurship. In doing so, we thus abstain from making a simple, unidirectional, and causal argument that religious beliefs cause behavior (for a critique on such an approach, see Chaves (2010)). In our empirical analyses, we verify whether values indeed have the expected suppressing effect.

\section{Data and methods}

\subsection{Sample}

The empirical analyses were performed using data from the European Social Survey (ESS) ${ }^{7}$, a cross-national survey that has been in existence since 2001. Since 2002, face-to-face interviews have been conducted every two years in most European countries, as well as in the neighboring countries of Turkey, Israel, and the Russian Federation (see Appendix A for an overview of the countries included in the analysis sample). This process has resulted in eight survey rounds to date (2002-2016), from which the data have been harmonized into an international data file for all countries that participated in at least two rounds. In every survey round, a different representative cross-section of the adult population has been interviewed. Our analyses are restricted to individuals of working age (18-65 years old). From the first wave in 2002 onwards, the ESS has included measures of the religion, values, and employment status of the respondents. Our sample comprises 150,498 individuals from 189 country-wave combinations.

\subsection{Measures}

\subsubsection{Entrepreneurship}

Based on the employment relationship of each respondent, we constructed the variable entrepreneurship, which takes the value 1 for self-employed individuals and 0 for wage workers. This variable distinguishes the occupations of individuals who operate their businesses

\footnotetext{
$\overline{{ }^{7} \mathrm{http}: / / \text { www.europeansocialsurvey.org/. }}$
} 
independently without the control of supervisors from those of people who have employers and who are not fully responsible for the survival of the business (Wennekers \& Thurik, 1999). We consider only individuals who indicate that paid work has been their main activity in the past 7 days and exclude those who are unemployed, retired, permanently sick, or disabled. Moreover, those indicating that they are primarily engaged in following education (not paid for by employer), community or military service, housework, or looking after children or others are also excluded. For heterogeneity analyses, we exploit information about the number of hours worked per week and the number of employees to serve as a proxy for engagement in and efforts to expand the business.

\subsubsection{Belonging to a (particular) religion}

Saroglou et al. (2004) show that differences in value priorities are most eminent between religious and nonreligious people but that there is also some heterogeneity within the first group depending on the particular religion someone belongs to. Therefore, we analyze both the self-identifiedbelonging to a religion $(1=$ yes; $0=$ no) as well as whether someone belongs to a particular religion or denomination. For the latter, we can distinguish in the dataset among individuals who self-identify as Roman Catholic, Protestant, Eastern Orthodox, Jewish, or Islamic. The composite groups of individuals belonging to other Christian denominations, Eastern religions, and other non-Christian religions are too small and too heterogeneous to consider for separate analyses and are therefore excluded.

Still, belonging to a religion does not always indicate active religious participation and strong beliefs, and therefore, we follow the proposal of Billiet (2001) in the ESS documentation to construct the variable religiously active as the first standardized principal component of the three ordinal variables in the dataset. Specifically, the respondents were asked to answer the following questions: (i) "How religious are you?" on an 11point scale, ranging from "not at all religious" to "very religious"; (ii) "How often do you attend religious services apart from on special occasions?" on a 7-point scale, ranging from "never" to "everyday"; and (iii) "How often do you pray apart from at religious services?" on the same 7-point scale, ranging from "never" to "everyday." Cronbach's $\alpha$ is 0.80 for this composite score, indicating high internal reliability. The higher a person scores on this variable, the more actively this person engages in a religion.

\subsubsection{Values}

Individual value priorities are assessed using the socalled Portrait Values Questionnaire (PVQ), which is based on Schwartz's basic human values theory. EVery respondent self-reports on resemblances with short verbal portraits of individuals (Schwartz, 2001). Each portrait describes an individual's goals, aspirations, or wishes that point implicitly to the importance of a particular value. For example, one portrait (indexing self-enhancement) reads: "It's important to her/him to show her/his abilities. She/he wants people to admire what she/he does." For each portrait, respondents answer the question, "How much like you is this person?" on a 6-point scale, ranging from "not like me at all" to "very much like me." In total, resemblance with 21 portraits is assessed in the ESS. The full list of 21 portraits is available in Appendix B (Table 8). Cronbach's $\alpha$ for the 21 items is 0.83 in our analysis sample. We compute summary scores for the four value groups by calculating the means of the items that index them. Cronbach's $\alpha$ for openness to change (6 items) is 0.75 , for conservation $\left(6\right.$ items $\left.^{8}\right)$ is 0.72 , for selfenhancement (4 items) is 0.74 , and for self-transcendence (5 items) is 0.73 . Subsequently, as recommended, we subtract each individual's mean score over all 21 value items from these summary scores to correct for response style differences between individuals and cultural groups (Schwartz, 2001).

\subsubsection{Methodology}

Following the recommendation of the ESS, we use poststratification weights in combination with population size weights to account for possible sampling bias and to correct for the fact that countries have different population sizes but approximately equal sample sizes in the

\footnotetext{
${ }^{8}$ One of these items is "Tradition is important to him. He tries to follow the customs handed down by his religion or his family", and it may therefore be a concern that belonging to a religion is part of conservation. However, the empirical results do not change meaningfully when this item is not used for constructing conservation (the correlation between conservation and the adjusted measure for conservation is 0.94 ). The results of this robustness check are available upon request from the authors.
} 
survey (European Social Survey, 2014). ${ }^{9}$ In Section 4.1, we provide descriptive evidence about the relationship between religion, values, and entrepreneurship. In Section 4.2, we use logit models explaining the binary variable entrepreneurship to answer the question whether values explain the relationship between belonging to a religion and entrepreneurship. We use the method developed by Karlson, Holm, and Breen (2012)(hereafter KHB-procedure) to assess the change in the coefficient for belonging to a religion and its significance when adding values as explanatory variables to the regression. This change is proportional to the explanatory power of values in the relationship between belonging to a religion and entrepreneurship (i.e., the sum of the effect of belonging to a religion on entrepreneurship through values and the effect of entrepreneurship on belonging to a religion through values; see Section 2.4).

In non-linear models, such as the logit model, the coefficients and the error variance are not separately identified. Therefore, the coefficients for belonging to a religion in the basic and extended models (including values) cannot be directly compared. The procedure of Karlson et al. (2012) has the advantage of separating the change in coefficients due to adding variables to the regression from the change due to non-linear rescaling. Due to the recommended correction for response style differences (see Section 3.2.3), the four higher-order values are jointly perfectly collinear and cannot all four simultaneously be included in a regression. Therefore, we include each bipolar value dimension separately in an extended model.

In our models, we abstain from including control variables which are likely to be endogenous (e.g., one's education attainment may be a function of someone's religious upbringing, may affect value priorities, and may influence the choice of entrepreneurship) and their inclusion may adversely affect adequate answering of our research question. Therefore, we control for the following factors only. Previous studies have convincingly shown that males are more likely to engage in entrepreneurship than females (Haber, Lamas \& Lichtenstein, 1987; Verheul, Van Stel \& Thurik, 2006), whereas the opposite is generally true for engagement in a religion (Loewenthal, MacLeod \& Cinnirella, 2002). Therefore, the dummy variable male, with a value of 1 for males and 0 for females, is included as

\footnotetext{
${ }^{9}$ Additional analyses show the influence of the post-stratification weights is marginal. Our empirical results are quantitatively and qualitatively similar when using or not using these weights.
}

a control variable in the regression. The relationship between age and entrepreneurship is known to be inverse Ushaped(Lévesque \& Minniti, 2006), and Argue, Johnson, and White (1999) found that age is also associated with religiosity. Therefore, both age (in years) and $a g e^{2}$ are included in the model. To control for possible structural differences across countries and over the years of data collection, we include dummy variables for each country and every data collection year (biennial from 2002 to 2016) in the regressions. ${ }^{10}$ The variance inflation factors of the various models do not reveal concerns for multicollinearity.

\section{Results}

\subsection{Descriptive statistics}

Our analysis sample comprises 150,498 individuals from 32 countries who are aged between 18 and 65 years and are either engaged in entrepreneurship $(13.54 \%)$ or wage workers $(86.46 \%)$. In Appendix A, we provide a full description of how the analysis sample was obtained from the full ESS dataset. The (weighted) descriptive statistics of the analysis sample are shown in Table 3. Compared with the wage workers, the entrepreneurs more often belong to a religion (59\% vs. 54\%). They self-identify more often as Roman Catholic, Jewish, and Islamic but less often as Protestant and Eastern Orthodox. Relatedly, entrepreneurs are more religiously active than wage workers. Regarding values, openness to change and self-enhancement are rated highest by the entrepreneurs and conservation and self-transcendence by the wage workers. Finally, in our sample, the percentage of males is, not surprisingly, higher among the entrepreneurs than among the wage workers (69\% versus $53 \%$ ), and the entrepreneurs are, on average, 3.40 years older than the wage workers. Bivariate correlations between variables are available in Table 9 in the Appendix.

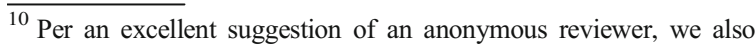
investigated the robustness of our results with regard to the inclusion of Hofstede's cultural dimensions as control variables. In order to include the Hofstede's six cultural dimensions in the model, we need to drop the country dummies as the time-invariant nature of Hofstede's dimensions makes that the dimensions are perfectly collinear with the country and wave dummies. The results show that the inclusion of Hofstede's cultural dimensions in the model has qualitatively the same effect as the inclusion of country dummies. These results are available upon request from the authors.
} 
Table 3 Weighted descriptive statistics analysis sample. Mean values are reported with standard deviations in parentheses

\begin{tabular}{|c|c|c|c|c|}
\hline & Full sample $(N=150,498)$ & Entrepreneurs $(N=20,377)$ & Wage workers $(N=130,121)$ & $p$ value \\
\hline \multicolumn{5}{|l|}{ Religion } \\
\hline Belonging to a religion $(0 / 1)$ & $0.55(0.50)$ & $0.59(0.49)$ & $0.54(0.50)$ & $<0.001$ \\
\hline Roman Catholic (0/1) & $0.28(0.45)$ & $0.34(0.47)$ & $0.27(0.45)$ & $<0.001$ \\
\hline Protestant $(0 / 1)$ & $0.10(0.30)$ & $0.09(0.28)$ & $0.10(0.30)$ & $<0.001$ \\
\hline Eastern Orthodox $(0 / 1)$ & $0.11(0.32)$ & $0.08(0.28)$ & $0.12(0.32)$ & $<0.001$ \\
\hline Jewish $(0 / 1)$ & $0.01(0.09)$ & $0.01(0.11)$ & $0.01(0.09)$ & $<0.001$ \\
\hline Islamic $(0 / 1)$ & $0.04(0.21)$ & $0.06(0.24)$ & $0.04(0.20)$ & $<0.001$ \\
\hline Religiously active & $-0.02(1.00)$ & $0.09(1.07)$ & $-0.03(1.00)$ & $<0.001$ \\
\hline \multicolumn{5}{|l|}{ Values } \\
\hline Openness to change & $-0.15(0.60)$ & $-0.09(0.59)$ & $-0.16(0.60)$ & $<0.001$ \\
\hline Conservation & $0.02(0.59)$ & $-0.04(0.62)$ & $0.03(0.58)$ & $<0.001$ \\
\hline Self-enhancement & $-0.52(0.73)$ & $-0.48(0.75)$ & $-0.53(0.72)$ & $<0.001$ \\
\hline Self-transcendence & $0.58(0.53)$ & $0.54(0.53)$ & $0.58(0.53)$ & $<0.001$ \\
\hline \multicolumn{5}{|l|}{ Control variables } \\
\hline Male $(0 / 1)$ & $0.55(0.50)$ & $0.69(0.46)$ & $0.53(0.50)$ & $<0.001$ \\
\hline Age (18-65) & $41.12(11.48)$ & $44.08(10.64)$ & $40.68(11.54)$ & $<0.001$ \\
\hline
\end{tabular}

The $p$ value indicates test results for differences in the means between the two occupational groups. Bivariate correlations between these variables are available in Table 9 in the Appendix. Descriptive statistics for the country and data collection rounds are available in Table 7 in the Appendix

The $p$ value indicates test results for differences in the means between the two occupational groups. Bivariate correlations between these variables are available in Table 9 in the Appendix. Descriptive statistics for the country and data collection rounds are available in Table 7 in the Appendix

The value priorities (in their deviation from an individual's mean value priority, see Section 3.2.3) are graphically depicted in Figs. 3 and 4. Figure 3 shows that irrespective of whether someone belongs to a religion or someone's occupational status, on average selftranscendence is the most important and self-enhancement the least important value. The priority order of values is similar for both occupational groups. However, importantly, for those belonging to a religion, conservation is more important than openness to change, whereas the opposite is true for those not belonging to a religion. Figure 4 shows that this pattern for openness to change and conservation is similar for each major religion in Europe.

\subsection{Multivariate analyses}

\subsubsection{Belonging to a religion}

Table 4 reports the results of the logistic regressions explaining entrepreneurship. The basic model includes only belonging to a religion and the control variables. In this model, belonging to a religion is not significantly associated with the outcome variable. The coefficients of the control variables are in the expected direction: Males are more often engaged in entrepreneurship than females, and the relation between age and entrepreneurship follows an inverse $\mathrm{U}$ shape. When including openness to change and conservation in the basic model, the coefficient for belonging to a religion increases and becomes significant. For ease of interpretation, coefficients are displayed as average marginal effects indicating that someone who belongs to a religion has a 1 percentage point higher chance of being an entrepreneur (Table 4, model 2). The KHB-procedure calculates that the increase is positive and significant $(p<0.001)$. Hence, without including these values (which can be seen as bidirectional mediating variables), the coefficient for belonging to a religion is suppressed. The inclusion of self-enhancement and self-transcendence in model 3 does not influence the significance of the coefficient for belonging to a religion despite selfenhancement and self-transcendence being significantly associated with entrepreneurship.

\subsubsection{Belonging to a particular religion}

Table 5 displays results for belonging to a particular religion. In the basic model, we see that Protestants are 

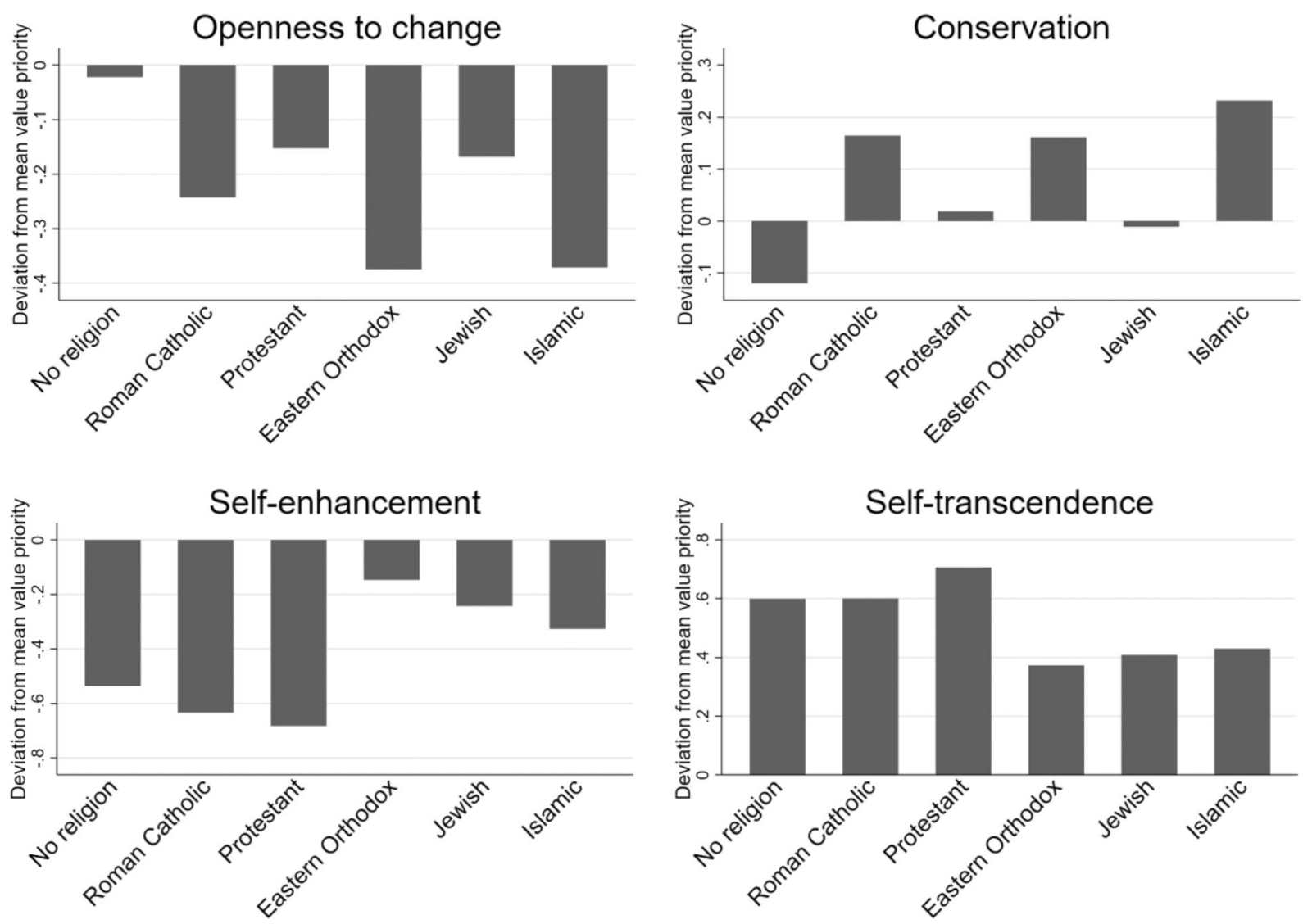

Fig. 4 Mean value priorities by belonging to a particular religion (weighted descriptive statistics)

less likely than those not belonging to a religion or denomination to be engaged in entrepreneurship. On the opposite, the Jewish are more likely to be an entrepreneur than the reference group. The coefficients for Roman Catholic, Eastern Orthodox, and Islamic are not statistically significant. The inclusion of openness to change and conservation in model 2 renders the coefficients for Roman Catholic and Islamic significant. The coefficient for Protestant becomes insignificant, and for Jewish, it remains similar in size and significance. For Eastern Orthodox, the coefficients remain insignificant. Nevertheless, in all cases, the average marginal effects have increased compared to those in model 1 , indicating that the value dimension openness
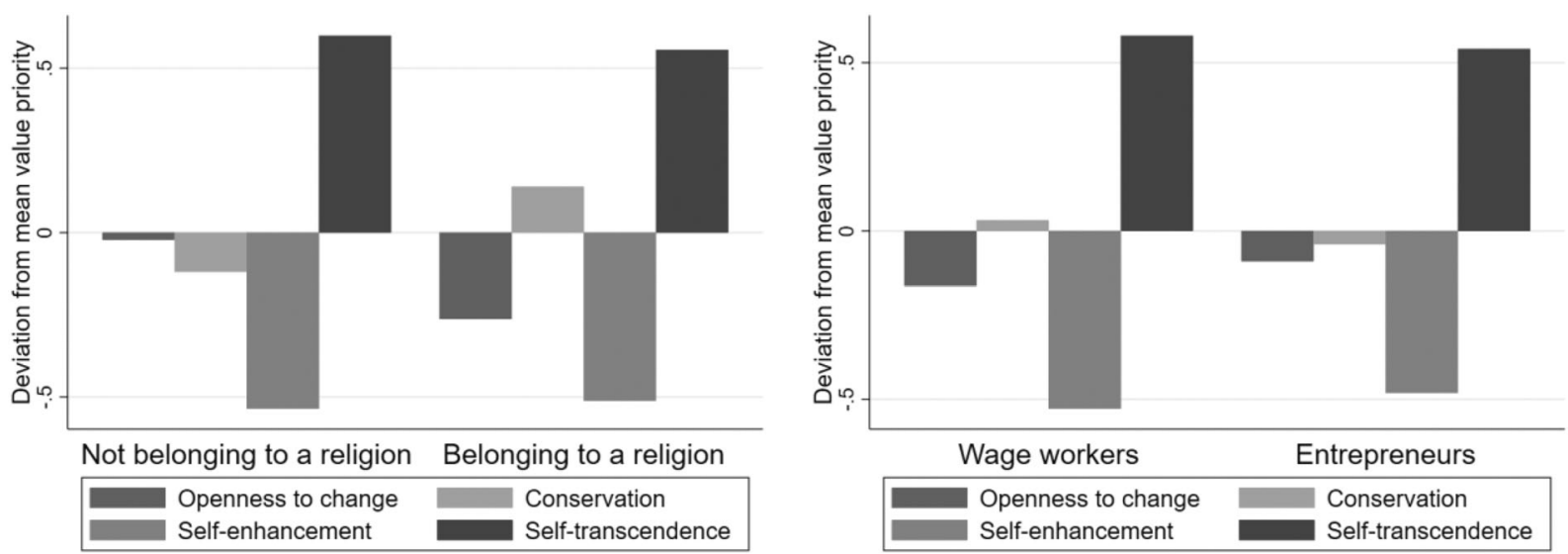

Fig. 3 Mean value priorities by belonging to a religion and occupational status (weighted descriptive statistics) 
Table 4 Logit regression models with entrepreneurship as the dependent variable $\begin{array}{ll}\text { (1) Basic model } & \text { (2) Basic model + value dimension } \\ \text { openness to change vs. conservation }\end{array}$
(3) Basic model + value dimension self-enhancement vs. self-transcendence

\section{Religion}

Belonging to a religion $\quad-0.002$

(0.003)

$0.010 * *$

$-0.002$

Values

Openness to change

$0.020 * * *$

Conservation

$-0.036^{* * *}$

(0.004)

Self-enhancement

Self-transcendence

(0.003)

-0.013 ***

(0.004)

Control variables

Male (0/1)

$0.072 * * *$

$0.069 * * *$

$0.067 * * *$

(0.003)

Age (18-65)

$0.012 * * *$

(0.003)

(0.003)

(0.001)

$0.013 * * *$

$0.012 * * *$

Age $^{2}$

$-0.000 * * *$

(0.001)

(0.001)

Country dummies

(0.000)

$-0.000^{* * *}$

$-0.000^{* * *}$

Included

(0.000)

(0.000)

Wave dummies

Included

Included

Included

Observations

150,498

Included

Included

150,498

150,498

Pseudo-R ${ }^{2}$

0.058

Average marginal effects are displayed with standard errors between parentheses. The intercept and average marginal effects for the country and wave dummies are not displayed but are available on request

$* * * p$ value $\leq 0.001, * * p$ value $\leq 0.01, * p$ value $\leq 0.05$ (two sided)

to change vs. conservation discriminates to some extent those belonging to a religion from entrepreneurs. It can be derived from Model 3 that the value dimension self-enhancement $\mathrm{vs.} \mathrm{self-transcendence} \mathrm{does} \mathrm{not} \mathrm{have}$ this discriminatory relevance: The regression coefficients for the religious groups and denominations remain similar in size and significance after extending the basic model with self-enhancement and selftranscendence.

\subsubsection{Engaging actively in a religion}

To assess whether the strength of the relationship between belonging to a religion, values and entrepreneurship (Section 4.2.1) depends on how actively someone's engages in a religion, we reanalyze the subsample of individuals belonging to a religion $(N$
$=83,113)$. In this subsample, we find that there is a significant relationship between religiously active and entrepreneurship (Table 6). This result is interesting because the relationship between belonging to a religion and entrepreneurship was insignificant in Table 4. The KHB-procedure indicates that the inclusion of the value dimension openness to change vs. conservation increases the coefficient for religiously active $(p<0.001)$, which corresponds to the implications of model 2 in Table 4. Interestingly, the inclusion of the value dimension self-enhancement vs. self-transcendence in model 3 results in a significant positive change $(p<0.001)$ in the coefficient for religiously active, something we did not observe in Table 4. Still, the change in the coefficient in model 3 is relatively small compared to the change in model 2. 
Table 5 Logit regression models with entrepreneurship as the dependent variable

$\begin{array}{lll}\text { (1) Basic model } & \begin{array}{l}\text { (2) Basic model + value } \\ \text { dimension openness to change vs. }\end{array} & \begin{array}{l}\text { (3) Basic model + value dimension } \\ \text { self-enhancement vs. self-transcendence }\end{array} \\ & \text { conservation }\end{array}$

\section{Religion}

Not belonging to a religion

Roman Catholic

Protestant

Eastern Orthodox

Jewish

Islamic

Islamic

Values

Openness to change

Conservation

Self-enhancement

Self-transcendence

$\begin{array}{lll}\text { Reference } & \text { Reference } & \text { Reference } \\ 0.002 & 0.015 * * * & 0.002 \\ (0.004) & (0.004) & (0.004) \\ -0.012^{*} & -0.002 & -0.012 * \\ (0.005) & (0.005) & (0.005) \\ -0.008 & -0.002 & -0.009 \\ (0.010) & (0.010) & (0.010) \\ 0.090 * & 0.094 * * & 0.084 * \\ (0.037) & (0.034) & (0.036) \\ 0.016 & 0.039 * * & 0.014 \\ (0.013) & (0.014) & (0.013)\end{array}$

$0.020 * * *$

(0.004)

$-0.037 * * *$

(0.004)

Control variables

Male (0/1)

Age (18-65)

Age $^{2}$

Country dummies

Wave dummies

Observations

Pseudo- $R^{2}$

$0.071 * * *$
$(0.003)$
$0.012 * * *$
$(0.001)$
$-0.000 * * *$
$(0.000)$
Included
Included
150,498
0.058

$0.017 * * *$

(0.003)

$-0.013 * * *$

(0.004)

$0.068 * * *$
$(0.003)$
$0.013 * * *$
$(0.001)$
$-0.000 * * *$
$(0.000)$
Included
Included
150,498
0.068

0.068 ***

$0.067 * * *$

(0.003)

$0.012 * * *$

(0.001)

$-0.000 * * *$

(0.000)

Included

Included

150,498

0.061

Average marginal effects are displayed with standard errors between parentheses. The intercept and average marginal effects for the country and wave dummies are not displayed but are available on request

$* * * p$ value $\leq 0.001, * * p$ value $\leq 0.01, * p$ value $\leq 0.05$ (two sided)

\subsubsection{Types of entrepreneurship}

In the analyses above, we compared entrepreneurs with wage workers without scrutinizing the heterogeneity within entrepreneurship. Within the limitations of the available information in the ESS, we therefore reanalyze the subset $(N=20,377)$ of entrepreneurs by looking at the number of hours they work and the number of employees they have in their business. Information about the average number of working hours per week is available for 17,670 entrepreneurs, of which $570(3 \%)$ work fewer than 20, 2729 (15\%) work between 20 and 40, 9006 (51\%) work 40-60, and 5065 (29\%) work more than $60 \mathrm{~h}$ per regular week. Information about 
Table 6 Logit regression models with entrepreneurship as the dependent variable

\begin{tabular}{|c|c|c|c|}
\hline & (1) Basic model & $\begin{array}{l}\text { (2) Basic model + value dimension } \\
\text { openness to change vs. conservation }\end{array}$ & $\begin{array}{l}\text { (3) Basic model + value dimension } \\
\text { self-enhancement vs. self-transcendence }\end{array}$ \\
\hline \multicolumn{4}{|l|}{ Religion } \\
\hline Religiously active & $\begin{array}{l}0.006^{*} \\
(0.002)\end{array}$ & $\begin{array}{l}0.011 * * * \\
(0.002)\end{array}$ & $\begin{array}{l}0.007 * * \\
(0.002)\end{array}$ \\
\hline \multicolumn{4}{|l|}{ Values } \\
\hline Openness to change & & $\begin{array}{l}0.018 * * \\
(0.006)\end{array}$ & \\
\hline Conservation & & $\begin{array}{l}-0.036^{* * * *} \\
(0.006)\end{array}$ & \\
\hline Self-enhancement & & & $\begin{array}{l}0.015 * * * \\
(0.004)\end{array}$ \\
\hline Self-transcendence & & & $\begin{array}{l}-0.021 * * * \\
(0.006)\end{array}$ \\
\hline \multicolumn{4}{|l|}{ Control variables } \\
\hline Male $(0 / 1)$ & $\begin{array}{l}0.080 * * * \\
(0.004)\end{array}$ & $\begin{array}{l}0.078 * * * \\
(0.004)\end{array}$ & $\begin{array}{l}0.075^{* * *} \\
(0.004)\end{array}$ \\
\hline Age (18-65) & $\begin{array}{l}0.011^{* * *} \\
(0.001)\end{array}$ & $\begin{array}{l}0.012 * * * \\
(0.001)\end{array}$ & $\begin{array}{l}0.012 * * * \\
(0.001)\end{array}$ \\
\hline $\mathrm{Age}^{2}$ & $\begin{array}{l}-0.000 * * * \\
(0.000)\end{array}$ & $\begin{array}{l}-0.000 * * * \\
(0.000)\end{array}$ & $\begin{array}{l}-0.000 * * * \\
(0.000)\end{array}$ \\
\hline Country dummies & Included & Included & Included \\
\hline Wave dummies & Included & Included & Included \\
\hline Observations & 83,113 & 83,113 & 83,113 \\
\hline Pseudo $\mathrm{R}^{2}$ & 0.067 & 0.074 & 0.070 \\
\hline
\end{tabular}

Average marginal effects are displayed with standard errors between parentheses. The intercept and average marginal effects for the country and wave dummies are not displayed but are available on request

$* * * p$ value $\leq 0.001, * * p$ value $\leq 0.01, * p$ value $\leq 0.05$ (two sided)

the number of employees is available for 19,573 entrepreneurs. Of these, 11,211 (57\%) have no employees, 7368 (38\%) have 1-10 employees, and 994 (5\%) have more than 10 employees.

Figure 5 shows that irrespective of the number of working hours or the number of employees, self-transcendence is rated highest and self-enhancement is rated lowest, which corresponds with the main observations in Fig. 3. Interestingly, the observation from Fig. 3 that entrepreneurs rate conservation a little higher than openness to change seems to be driven by those working more than $40 \mathrm{~h} /$ week and having fewer than $10 \mathrm{em}-$ ployees. Hence, from a value perspective, belonging to a religious group or denomination seems to fit mostly with working many hours in a small business.

\section{Discussion and conclusion}

Based on Schwartz's theory of basic human values, we analyzed how religion and entrepreneurship are linked through values. We predicted and found that the value priorities of individuals belonging to a religion are different from these of entrepreneurs. Values do explain, to some extent, the relation between religion and entrepreneurship: contrasting value priorities of those belonging to a religion and entrepreneurs weaken this relationship. Heterogeneity analyses show that these results are fairly similar across the major religions in Europe but do depend on how actively people engage in a religion. Moreover, from a value perspective, belonging to a religion seems to fit best with working many hours in a small business. 
Our findings supplement the literature in several ways. First, we contribute to research on religion and entrepreneurship by investigating a specific channel through which religion and entrepreneurship are connected. While past research empirically analyzed the direct relationship between religion and entrepreneurship, it did not address the specific indirect relationships that make up the full relationship at a micro-level(Block et al., 2019). As these indirect factors may vary over time and across countries, conclusions about the net relationship are difficult to generalize. Our study contributes to this stream of the literature by investigating one important channel through which religion and entrepreneurship are connected: values.

Second, by introducing a cross-culturally validated system of values by means of Schwartz's theory of basic human values (Schwartz, 1992, 2012), we are able to actually generate expectations about how values serve as a pathway through which religion and entrepreneurship are related. While past research hinted at the importance of values in the relationship between religion and entrepreneurship (Dana, 2009; Audretsch et al., 2013; Hoogendoorn et al., 2016), we theorize and empirically test this channel. Moreover, our theorizing concerns the values of individuals belonging to a religion as well as these of entrepreneurs, where past research focused on the values of religious individuals in a unidirectional sense (Audretsch et al., 2013; Dana 2009; Dougherty et al., 2019). Additionally, we go beyond previous research by exploiting the structure of the theory of basic human values which allows for the analysis of value priorities and of the conflicts and compatibility between values. Herewith, we allow for more complexity in our argumentation than previous studies, including those drawing on the famous Weber thesis (Carroll \& Mosakowski, 1987; Minns \& Rivov, 2005).

By introducing the theory of basic human values, we amend our understanding of engagement in entrepreneurship by taking account of values as motivational concepts influencing an individual's judgments, actions, and behavior (Arieli et al., 2019). We believe it is worthwhile to apply the theory of basic human values to investigate other phenomena in the entrepreneurship area, for example, to explain why entrepreneurship is a male-dominated occupation. Moreover, differences in value priorities between males and females might also explain why females are more likely to pursue societal goals with their business (Hechavarría et al. 2017). Schwartz's theory may also be useful for investigating how religion and individual values guide decisionmakingwithin businesses. Religious entrepreneurs tend to see running their businesses as a type of faithful vocation (Griebel, Park \& Neubert, 2014; Rietveld \& Van Burg 2014), which may affect specific firm behaviors. For example, research has shown that religious individuals tend to hold broader conceptions of the social responsibilities of businesses than nonreligious individuals (Brammer, Williams \& Zinkin, 2007). With respect to values, Gorgievski, Ascalon, and Stephan (2011) show that business owners who favor self-enhancement put more emphasis on the success criteria profitability and business growth, while those who value self-transcendence tend to strive for a good balance between work and private life and for satisfied stakeholders.
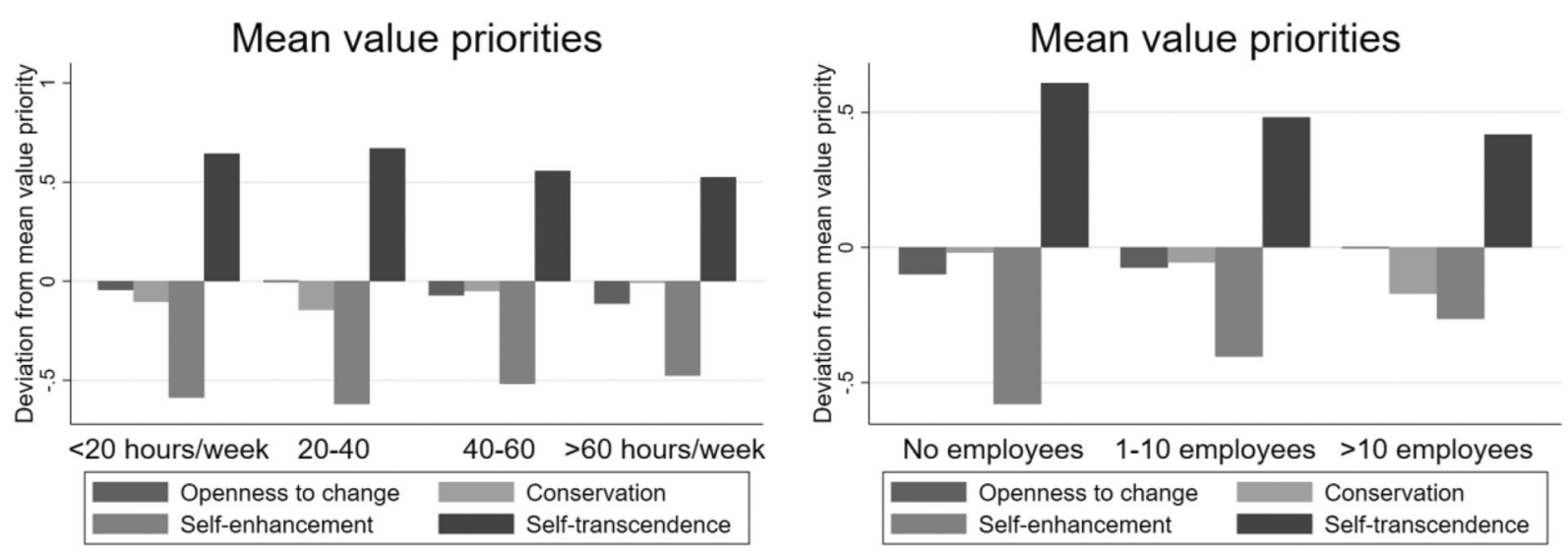

Fig. 5 Mean value priorities among the entrepreneurs by the number of working hours per week and the number of employees (weighted descriptive statistics) 
As such, there is a broad scope for future studies combining religion and values in general to further scrutinize the heterogeneity in the start-up motivations and decision-making of business owners because entrepreneurship is an occupation that particularly provides meaning and purpose and allows one to live one's values (Balog et al., 2013; Griebel, Park \& Neubert, 2014).

Third, we not only theorized but also empirically tested directly whether values indeed explain the reciprocal relationship between religion and entrepreneurship. Our findings show that not all values are equally important for explaining this relationship: it is the conflict between openness to change and conservation that tempers the relationship between belonging to a religion and entrepreneurship; the conflict between self-transcendence and self-enhancement does not have such a cushioning effect. The latter unexpected results may be explained by the observation that economic and employment factors relate primarily to values that directly concern workplace behavior such as independent thought, action, and achievement and less to the concern for the enhancement of the welfare of others such as in a family context (Longest et al., 2013). Therefore, future research could take account of a broader social influence on the development of values or the situational circumstances that stimulate or suppress the expression of values, as per the situational strength theory (Cooper \& Withey, 2009).

Although we find that the direction of effects of openness to change and conservation is similar across the major religions in Europe, there are some interesting variations. Most importantly, we find that there is variation across religions in favoring conservation over openness to change as well as differences in engagement in entrepreneurship. The meta-analysis by Saroglou et al. (2004) already showed that the relation between religion and values is rather similar across different religions and denominations. The relatively small differences across religions may nevertheless be attributed to the socio-economic development of countries (Saroglou et al., 2004). Indeed, it has repeatedly been suggested that individual value priorities depend on socio-economic factors such as economic development, modernization, and political democratization (Inglehart \& Baker, 2000; Schwartz \& Sagie, 2000). These factors may also have contributed to the inconsistent results of the earlier, mainly single-country, studies on the relation between religion and entrepreneurship (see Table 1). Finally, we find that the distinction between belonging to a religion and active engagement is highly relevant, as the strength of the relationship between belonging to a religion and entrepreneurship depends on how actively one engages in religion. Active engagement or identification with a religion may results in conformity to group values and norms, and as identities become more salient, the associated behaviors may be more strongly affected (Benjamin, Choi \& Fisher, 2016). A path for future research may therefore concern how one's identification with a particular religious group influences one's career choice, for example, by means of social identity theory (Tajfel \& Turner, 1986; Akerlof \& Kranton, 2000).

Our study is not without limitations. We note that most countries in our sample are developed countries in which Christianity is the most important religion (at least historically). Although we addressed whether our results are driven by factors associated with an individual's belonging to a particular religion, our results may not be generalizable to countries with a different religious or cultural tradition (Candland, 2000). Moreover, we analyzed the role of values at the individual level, but (religious) values are also believed to be embedded in society and to form a part of informal institutions with a persistent influence on the long-term character of the society's economy (North, 1991; Norris \& Inglehart, 2004; Williamson, 2000). For example, a recent study showed that the majority religion influences the country's business ownership level through the country's culture and institutions beyond the direct effect that religion has through the individuals who adhere to it (Zelekha, Avnomelelch \& Sharabi, 2014). Future studies might thus want to delve into the effects of the diversity and/or distinctiveness of values at both the individual and macro levels (Henley, 2014; Nikolova \& Simroth, 2015).

The analysis of the ESS comes with the advantage of having large-scale, harmonized individual-level information about religion, values, and employment status. However, importantly, the ESS surveys in each data collection wave different representative crosssection of the adult population. Also for this reason, we stress again (in line with Chaves, 2010) that any simple, unidirectional, and causal argument that religious beliefs cause behavior cannot be inferred 
from our empirical results. That is, the mediating effects constitute the sum of the effect of belonging to a religion on entrepreneurship through values and the effect of entrepreneurship on belonging to a religion through values. Moreover, some measures in the ESS are relatively crude. For example, individuals can indicate only the employment relation that describes them best, which leaves little room to scrutinize heterogeneity within entrepreneurship. Future studies analyzing for example motivational heterogeneity among entrepreneurs may as such provide more nuanced insights. Relatedly, the number of control variables in our models is relatively small because we purposely decided to not include possible endogenous control variables. Hence, our study provides empirical evidence about the full (bidirectional) relationship between religion and entrepreneurship through values, but future studies may investigate whether other factors influence these relationships.

Despite these limitations, we have made a step forward in this stream of the literature by directly analyzing one of the prominent channels through which religion and entrepreneurship are connected. We have argued and shown that values can explain the relation between religion and entrepreneurship. However, importantly, values weaken this relationship because of value inconsistencies between religion and entrepreneurship. While this may be a somewhat surprising result in a literature where Weber's theory about the Protestant work ethic is a dominant starting point for many, this study warrants the examination of other channels through which religion and entrepreneurship are related.

Acknowledgements The authors are grateful for the valuable comments of Joern Block, Kristel de Groot, Phillip Kim, and André van Stel on earlier versions of this paper. They also thank Reinier van Uden for excellent research assistance. This study uses the following dataset: European Social Survey Cumulative File, ESS 1-8(2018); Data file edition 1.0; NSD - Norwegian Centre for Research Data, Norway - Data Archive and distributor of ESS data for ESS ERIC.

\section{Appendix}

Analysis sample composition

The eight biennial data collection rounds (20022016) included in the international data file of the
European Social Survey (ESS) contain 374,729 observations from 32 countries. Not every country participated in every data collection wave, and hence, the data originate from 195 country-wave combinations rather than $256(32 \times 8)$ countrywave combinations. In our analyses, we focus on entrepreneurs and wage workers of working age (18-65 years old) active in the labor market, which reduces the sample to 174,881 observations from 192 country-wave combinations because employment status information is not available for France in waves 1 and 2 (the French questionnaire included two additional answer categories for this question) and Hungary in wave 2 (the Hungarian questionnaire included one additional answer category for this question) in the international data file. A further restriction was made to 160,651 observations from 190 country-wave combinations with complete information on value priorities because the Schwartz value scale was not fielded in Luxembourg in wave 1 and was completed only by males in Italy in wave 1 . Therefore, the ESS decided not to include the value data from Italy wave 1 in the international file. A subsequent restriction was imposed to 150,535 observations for which the variables belonging to a (particular) religion and religiously active could be constructed. These data originate from 189 country-wave combinations because the data from Finland wave 2 were all dropped as the question about adherence to a specific religion was asked differently than indicated in the ESS interview guidelines and hence was not included in the international data file. This process includes the removal of individuals in the composite groups of individuals belonging to other Christian denominations (1826), Eastern religions (577), and other non-Christian religions (414), which are too small and too heterogeneous to consider for separate analyses. Finally, 37 observations were dropped because of missing information about gender. Thus, our analysis comprises 150,498 individuals from 32 countries (189 country-wave combinations; see Table 7), which equals $40.2 \%$ of the original number of observations in the data file, and apart from the drop in specific country-wave combinations for reasons described above, the drop in observations because of missing data appears to be rather random. 
Table 7 Overview of observations per country and data collection wave in the analysis sample

\begin{tabular}{|c|c|c|c|c|c|c|c|c|c|c|}
\hline & \multirow[t]{2}{*}{ Country } & \multicolumn{8}{|c|}{ Data collection wave } & \multirow[t]{2}{*}{ Total } \\
\hline & & $\begin{array}{l}\text { Round } \\
1(2002)\end{array}$ & $\begin{array}{l}\text { Round } \\
\text { 2(2004) }\end{array}$ & $\begin{array}{l}\text { Round } \\
3(2006)\end{array}$ & $\begin{array}{l}\text { Round } \\
4(2008)\end{array}$ & $\begin{array}{l}\text { Round } \\
5(2010)\end{array}$ & $\begin{array}{l}\text { Round } \\
6(2012)\end{array}$ & $\begin{array}{l}\text { Round } \\
7(2014)\end{array}$ & $\begin{array}{l}\text { Round } \\
8(2016)\end{array}$ & \\
\hline 1 & Austria & 1117 & 850 & 1072 & 0 & 0 & 0 & 888 & 974 & 4901 \\
\hline 2 & Belgium & 805 & 779 & 836 & 830 & 795 & 861 & 824 & 808 & 6538 \\
\hline 3 & Bulgaria & 0 & 0 & 116 & 829 & 759 & 798 & 0 & 0 & 2502 \\
\hline 4 & Switzerland & 1021 & 1020 & 861 & 841 & 758 & 754 & 740 & 765 & 6760 \\
\hline 5 & Cyprus & 0 & 0 & 6 & 606 & 428 & 477 & 0 & 0 & 1517 \\
\hline 6 & Czech Republic & 486 & 964 & 0 & 925 & 1052 & 807 & 923 & 1233 & 6390 \\
\hline 7 & Germany & 1197 & 1128 & 1197 & 1298 & 1345 & 1299 & 1406 & 1367 & 10,237 \\
\hline 8 & Denmark & 820 & 728 & 764 & 839 & 743 & 805 & 712 & 0 & 5411 \\
\hline 9 & Estonia & 0 & 886 & 702 & 781 & 785 & 1051 & 996 & 1059 & 6260 \\
\hline 10 & Spain & 645 & 756 & 914 & 1230 & 843 & 744 & 742 & 831 & 6705 \\
\hline 11 & Finland & 894 & 0 & 562 & 946 & 739 & 1038 & 913 & 892 & 5984 \\
\hline 12 & France & 0 & 0 & 978 & 989 & 813 & 878 & 863 & 877 & 5398 \\
\hline 13 & UK & 815 & 487 & 656 & 1079 & 1016 & 898 & 947 & 863 & 6761 \\
\hline 14 & Greece & 978 & 839 & 0 & 1068 & 953 & 0 & 0 & 0 & 3838 \\
\hline 15 & Croatia & 0 & 0 & 0 & 443 & 442 & 0 & 0 & 0 & 885 \\
\hline 16 & Hungary & 640 & 0 & 530 & 517 & 639 & 793 & 696 & 719 & 4534 \\
\hline 17 & Ireland & 834 & 468 & 628 & 713 & 651 & 915 & 893 & 1144 & 6246 \\
\hline 18 & Israel & 878 & 0 & 0 & 998 & 823 & 1002 & 975 & 1005 & 5681 \\
\hline 19 & Iceland & 0 & 283 & 0 & 0 & 0 & 317 & 0 & 441 & 1041 \\
\hline 20 & Italy & 0 & 0 & 0 & 0 & 0 & 362 & 0 & 1002 & 1364 \\
\hline 21 & Lithuania & 0 & 0 & 0 & 0 & 476 & 894 & 937 & 903 & 3210 \\
\hline 22 & Luxembourg & 0 & 595 & 0 & 0 & 0 & 0 & 0 & 0 & 595 \\
\hline 23 & Netherlands & 999 & 800 & 844 & 823 & 845 & 820 & 789 & 717 & 6637 \\
\hline 24 & Norway & 1040 & 888 & 888 & 801 & 863 & 939 & 787 & 842 & 7048 \\
\hline 25 & Poland & 748 & 645 & 697 & 636 & 731 & 778 & 691 & 693 & 5619 \\
\hline 26 & Portugal & 654 & 769 & 824 & 836 & 677 & 707 & 470 & 541 & 5478 \\
\hline 27 & $\begin{array}{l}\text { Russian } \\
\text { Federation }\end{array}$ & 0 & 0 & 908 & 957 & 1055 & 1128 & 0 & 1008 & 5056 \\
\hline 28 & Sweden & 932 & 916 & 930 & 886 & 756 & 909 & 879 & 751 & 6959 \\
\hline 29 & Slovenia & 627 & 279 & 564 & 498 & 511 & 460 & 456 & 551 & 3946 \\
\hline 30 & Slovakia & 0 & 573 & 761 & 723 & 674 & 752 & 0 & 0 & 3483 \\
\hline 31 & Turkey & 0 & 427 & 0 & 482 & 0 & 0 & 0 & 0 & 909 \\
\hline \multirow[t]{2}{*}{32} & Ukraine & 0 & 552 & 551 & 477 & 464 & 561 & 0 & 0 & 2605 \\
\hline & Total & 16,130 & 15,632 & 16,789 & 22,051 & 20,636 & 21,747 & 17,527 & 19,986 & 150,498 \\
\hline
\end{tabular}




\section{Schwartz’ Portrait Values Questionnaire}

Table 8 The 21 portraits from the Schwartz's Portrait Values Questionnaire used to measure the higher-order and basic human values in the European Social Survey. For each portrait, respondents answer the question "How much like you is this person?" on a 6-point scale ranging from "not like me at all" to "very much like me"

\begin{tabular}{|c|c|c|}
\hline Value group & Basic human value & Portraits \\
\hline \multicolumn{3}{|c|}{ Bipolar dimension openness to change vs. conservation } \\
\hline \multirow[t]{6}{*}{ Openness to change } & Stimulation & $\begin{array}{l}\text { She/he likes surprises and is always looking for new things to do. She/he thinks } \\
\text { it is important to do lots of different things in life. }\end{array}$ \\
\hline & & She/he looks for adventures and likes to take risks. She/he wants to have an exciting life. \\
\hline & Self-direction & $\begin{array}{l}\text { Thinking up new ideas and being creative is important to her/him. She/he likes to } \\
\text { do things in her/his own original way. }\end{array}$ \\
\hline & & $\begin{array}{l}\text { It is important to her/him to make her/his own decisions about what she/he does. } \\
\text { She/he likes to be free and not depend on others. }\end{array}$ \\
\hline & Hedonism & Having a good time is important to her/him. She/he likes to "spoil" herself/himself. \\
\hline & & $\begin{array}{l}\text { She/he seeks every chance she/he can to have fun. It is important to her/him to } \\
\text { do things that give her/him pleasure. }\end{array}$ \\
\hline \multirow[t]{6}{*}{ Conservation } & Tradition & $\begin{array}{l}\text { It is important to her/him to be humble and modest. She/he tries not to draw attention } \\
\text { to herself/himself. }\end{array}$ \\
\hline & & $\begin{array}{l}\text { Tradition is important to her/him. She/he tries to follow the customs handed down by } \\
\text { her/his religion or her/his family. }\end{array}$ \\
\hline & Conformity & $\begin{array}{l}\text { She/he believes that people should do what they are told. She/he thinks people should } \\
\text { follow rules at all times, even when no-one is watching. }\end{array}$ \\
\hline & & $\begin{array}{l}\text { It is important to her/him always to behave properly. She/he wants to avoid doing } \\
\text { anything people would say is wrong. }\end{array}$ \\
\hline & Security & $\begin{array}{l}\text { It is important to her/him to live in secure surroundings. She/he avoids anything that } \\
\text { might endanger her/his safety. }\end{array}$ \\
\hline & & $\begin{array}{l}\text { It is important to her/him that the government ensures her/his safety against all } \\
\text { threats. She/he wants the state to be strong so it can defend its citizens. }\end{array}$ \\
\hline \multicolumn{3}{|c|}{ Bipolar dimension self-enhancement vs. self-transcendence } \\
\hline \multirow[t]{4}{*}{ Self-enhancement } & Power & $\begin{array}{l}\text { It is important to her/him to be rich. She/he wants to have a lot of money and } \\
\text { expensive things. }\end{array}$ \\
\hline & & $\begin{array}{l}\text { It is important to her/him to get respect from others. She/he wants people to do } \\
\text { what she/he says. }\end{array}$ \\
\hline & Achievement & $\begin{array}{l}\text { It is important to her/him to show her/his abilities. She/he wants people to admire } \\
\text { what she/he does. }\end{array}$ \\
\hline & & $\begin{array}{l}\text { Being very successful is important to her/him. She/he hopes people will } \\
\text { recognize her/his achievements. }\end{array}$ \\
\hline \multirow[t]{5}{*}{ Self-transcendence } & Universalism & $\begin{array}{l}\text { She/he thinks it is important that every person in the world should be treated equally. } \\
\text { She/he believes everyone should have equal opportunities in life. }\end{array}$ \\
\hline & & $\begin{array}{l}\text { It is important to her/him to listen to people who are different from her/him. } \\
\text { Even when she/he disagrees with them, she/he still wants to understand them. }\end{array}$ \\
\hline & & $\begin{array}{l}\text { She/he strongly believes that people should care for nature. Looking after the } \\
\text { environment is important to her/him. }\end{array}$ \\
\hline & Benevolence & $\begin{array}{l}\text { It is very important to her/him to help the people around her/him. She/he wants } \\
\text { to care for their well-being. }\end{array}$ \\
\hline & & $\begin{array}{l}\text { It is important to her/him to be loyal to her/his friends. She/he wants to devote } \\
\text { herself/himself to people close to her/him. }\end{array}$ \\
\hline
\end{tabular}




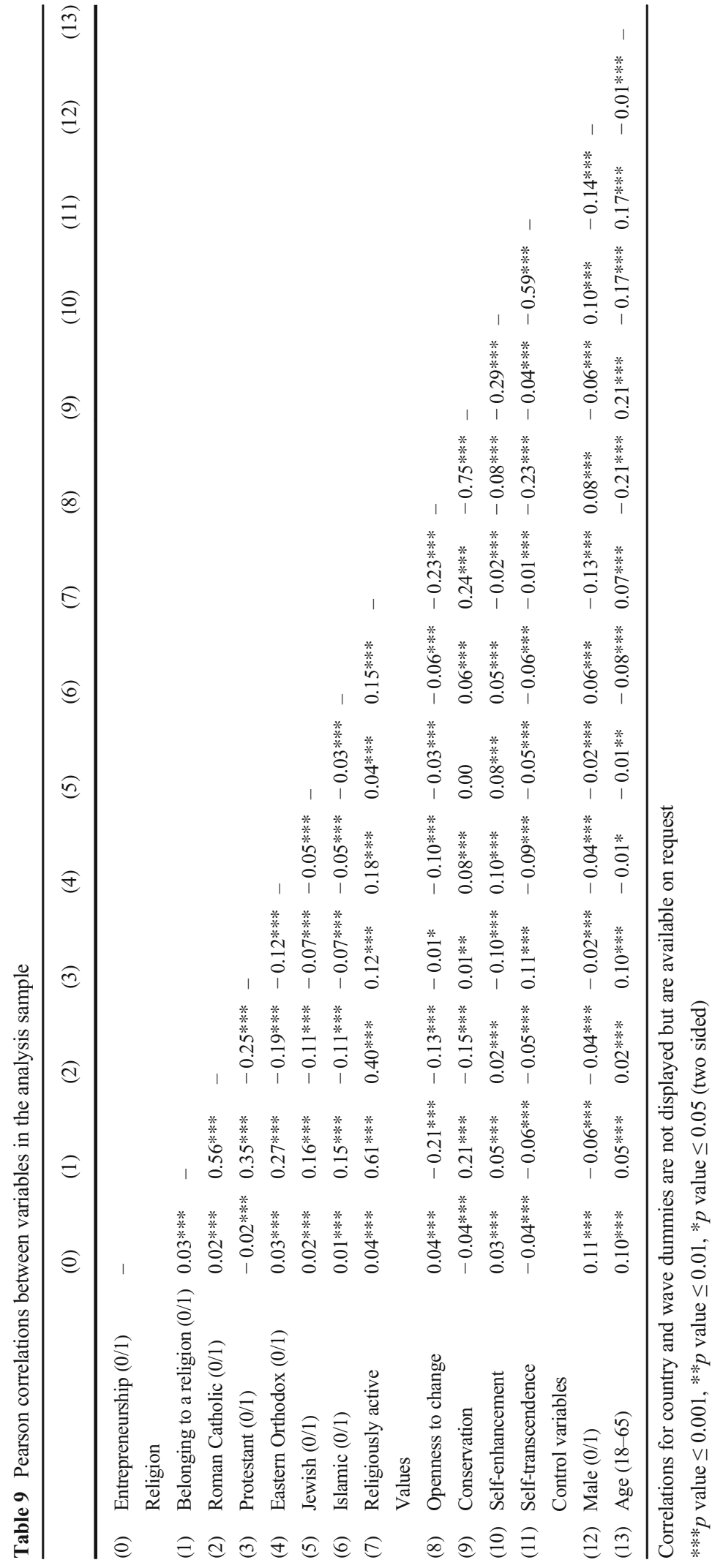


Open Access This article is licensed under a Creative Commons Attribution 4.0 International License, which permits use, sharing, adaptation, distribution and reproduction in any medium or format, as long as you give appropriate credit to the original author(s) and the source, provide a link to the Creative Commons licence, and indicate if changes were made. The images or other third party material in this article are included in the article's Creative Commons licence, unless indicated otherwise in a credit line to the material. If material is not included in the article's Creative Commons licence and your intended use is not permitted by statutory regulation or exceeds the permitted use, you will need to obtain permission directly from the copyright holder. To view a copy of this licence, visit http://creativecommons.org/licenses/by/4.0/.

\section{References}

Akerlof, G. A., \& Kranton, R. E. (2000). Economics and identity. Quarterly Journal of Economics, 115(3), 715-753.

Argue, A., Johnson, D. R., \& White, L. K. (1999). Age and religiosity: evidence from a three-wave panel analysis. Journal for the Scientific Study of Religion, 423-435.

Arieli, S., Sagiv, L., \& Roccas, S. (2019). Values at work: the impact of personal values in organisations. Applied Psychology. https://doi.org/10.1111/apps.12181.

Audretsch, D. B., Bönte, W., \& Tamvada, J. P. (2013). Religion, social class, and entrepreneurial choice. Journal of Business Venturing, 28(6), 774-789.

Balog, A. M., Baker, L. T., \& Walker, A. G. (2014). Religiosity and spirituality in entrepreneurship: a review and research agenda. Journal of Management, Spirituality \& Religion, 11(2), 159-186.

Benjamin, D. J., Choi, J. J., \& Fisher, G. (2016). Religious identity and economic behavior. Review of Economics and Statistics, 98(4), 617-637.

Beugelsdijk, S., \& Noorderhaven, N. (2005). Personality characteristics of self-employed; an empirical study. Small Business Economics, 24(2), 159-167.

Billiet, J. (2001). European Social Survey core questionnaire development-chapter 9: proposal for questions on religious identity. London: European Social Survey, City University London Retrieved from: http://www.europeansocialsurvey. org/docs/methodology/core_ess_questionnaire/ESS_core_ questionnaire_religious_identity.pdf.

Block, J., Fisch, C., \& Rehan, F. (2019). Religion and entrepreneurship: a map of the field and a bibliometric analysis. Management Review Quarterly.https://doi.org/10.1007 /s11301-019-00177-2.

Brammer, S., Williams, G., \& Zinkin, J. (2007). Religion and attitudes to corporate social responsibility in a large crosscountry sample. Journal of Business Ethics, 71(3), 229-243.

Butler, J. S., \& Herring, C. (1991). Ethnicity and entrepreneurship in America: toward an explanation of racial and ethnic group variations in self-employment. Sociological Perspectives, 34(1), 79-94.

Candland, C. (2000). Faith as social capital: religion and community development in Southern Asia. Policy Sciences, 33(3-4), 355-374.
Carroll, G. R., \& Mosakowski, E. (1987). The career dynamics of self-employment. Administrative Science Quarterly, 32(4), 570-589.

Carswell, P., \& Rolland, D. (2007). Religion and entrepreneurship in New Zealand. Journal of Enterprising Communities: People and Places in the Global Economy, 1(2), 162-174.

Chaves, M. (2010). Rain dances in the dry season: overcoming the religious congruence fallacy. Journal for the Scientific Study of Religion, 49(1), 1-14.

Cliff, J. E., Jennings, P. D., \& Greenwood, R. (2006). New to the game and questioning the rules: the experiences and beliefs of founders who start imitative versus innovative firms. Journal of Business Venturing, 21(5), 633-663.

Cooper, W. H., \& Withey, M. J. (2009). The strong situation hypothesis. Personality and Social Psychology Review, 13(1), 62-72.

Dana, L. P. (2009). Religion as an explanatory variable for entrepreneurship. The International Journal of Entrepreneurship and Innovation, 10(2), 87-99.

De Noble, A., Galbraith, C. S., Singh, G., \& Stiles, C. H. (2007). Market justice, religious orientation, and entrepreneurial attitudes: an empirical study. Journal of Enterprising Communities: People and Places in the Global Economy, 1(2), 121-134.

De Wit, G., \& De Kok, J. (2014). Do small businesses create more jobs? New evidence for Europe. Small Business Economics, 42(2), 283-295.

Dodd, S. D., \& Gotsis, G. (2007). The interrelationships between entrepreneurship and religion. The International Journal of Entrepreneurship and Innovation, 8(2), 93-104.

Dodd, S. D., \& Seaman, P. T. (1998). Religion and enterprise: an introductory exploration. Entrepreneurship: Theory and Practice, 23(1), 71-86.

Dougherty, K. D., Griebel, J., Neubert, M. J., \& Park, J. Z. (2013). A religious profile of American entrepreneurs. Journal for the Scientific Study of Religion, 52(2), 401-409.

Dougherty, K. D., Neubert, M. J., \& Park, J. Z. (2019). Prosperity beliefs and value orientations: fueling or suppressing entrepreneurial activity. Journal for the Scientific Study of Religion, 58(2), 475-493.

European Social Survey. (2014, July 9). Weighting European Social Survey Data. Retrieved from https://www. europeansocialsurvey.org/docs/methodology/ESS weighting_data_1.pdf

Geertz, C. (1993). Religion as a cultural system. In The interpretation of cultures: selected essays (pp. 87-125). New York: Basic Books.

Gorgievski, M. J., Ascalon, M. E., \& Stephan, U. (2011). Small business owners' success criteria, a values approach to personal differences. Journal of Small Business Management, 49(2), 207-232.

Griebel, J., Park, J., \& Neubert, M. (2014). Faith and work: an exploratory study of religious entrepreneurs. Religions, 5(3), 780-800.

Guiso, L., Sapienza, P., \& Zingales, L. (2006). Does culture affect economic outcomes? Journal of Economic Perspectives, 20(2), 23-48.

Haber, S. E., Lamas, E. J., \& Lichtenstein, J. H. (1987). On their own: the self-employed and others in private business. Monthly Labor Review, 110(5), 17-23. 
Hechavarría, D. M., Terjesen, S. A., Ingram, A. E., Renko, M., Justo, R., \& Elam, A. (2017). Taking care of business: the impact of culture and gender on entrepreneurs' blended value creation goals. Small Business Economics, 48(1), 225-257.

Henley, A. (2014). Is religion associated with entrepreneurial activity? IZA Discussion Paper, 8111.

Hessels, J., Rietveld, C. A., \& Van der Zwan, P. (2017). Selfemployment and work-related stress: the mediating role of job demand and job control. Journal of Business Venturing, 32(2), 178-196.

Hill, N. J., Perkins, S., \& White, J. (2015). The influence of religion on becoming an entrepreneur in the United States. Academy of Entrepreneurship Journal, 21(2), 15.

Hitlin, S. (2003). Values as the core of personal identity: drawing links between two theories of self. Social Psychology Quarterly, 66(2), 118-137.

Hodge, D. R. (2003). The intrinsic spirituality scale: a new sixitem instrument for assessing the salience of spirituality as a motivational construct. Journal of Social Service Research, 30(1), 41-61.

Hofstede, G., Hofstede, G. J., \& Minkov, M. (2010). Cultures and organizations: software of the mind (3rd ed.). New York: McGraw Hill Education.

Hoogendoorn, B., Rietveld, C. A., \& Van Stel, A. (2016). Belonging, believing, bonding, and behaving: the relationship between religion and business ownership at the country level. Journal of Evolutionary Economics, 26(3), 519-550.

Iannaccone, L. R. (1998). Introduction to the economics of religion. Journal of Economic Literature, 36(3), 1465-1495.

Inglehart, R., \& Baker, W. E. (2000). Modernization, cultural change, and the persistence of traditional values. American Sociological Review, 65(1), 19-51.

Karlson, K. B., Holm, A., \& Breen, R. (2012). Comparing regression coefficients between same-sample nested models using logit and probit: a new method. Sociological Methodology, 42(1), 286-313.

Knafo, A., Roccas, S., \& Sagiv, L. (2011). The value of values in cross-cultural research: a special issue in honor of Shalom Schwartz. Journal of Cross-Cultural Psychology, 42(2), 178-185.

Koellinger, P. D., \& Thurik, A. R. (2012). Entrepreneurship and the business cycle. Review of Economics and Statistics, 94(4), 1143-1156.

Kohn, M. L., \& Schooler, C. (1982). Job conditions and personality: a longitudinal assessment of their reciprocal effects. American Journal of Sociology, 87(6), 1257-1286.

Kojana, T. \& Mamabolo, A. (2020). Religious entrepreneurs' motives and practices in the different phases of the entrepreneurial process. International Review of Entrepreneurship, 18(3). Available online: https://www.senatehall. com/entrepreneurship?article $=661$.

Lehrer, E. L. (2004). Religion as a determinant of economic and demographic behavior in the United States. Population and Development Review, 30(4), 707-726.

Lévesque, M., \& Minniti, M. (2006). The effect of aging on entrepreneurial behavior. Journal of Business Venturing, 21(2), 177-194.

Licht, A. (2007). Entrepreneurial spirit and what the law can do about it. Comparative Labor Law \& Policy Journal, 28(4), $817-862$.
Licht, A. (2010). Entrepreneurial motivations, culture, and the law. In Freytag \& A. R. Thurik (Eds.), Entrepreneurship and culture (pp. 11-40). Berlin, Heidelberg: Springer-Verlag.

Loewenthal, K. M., MacLeod, A. K., \& Cinnirella, M. (2002). Are women more religious than men? Gender differences in religious activity among different religious groups in the UK. Personality and Individual Differences, 32(1), 133-139.

Longest, K. C., Hitlin, S., \& Vaisey, S. (2013). Position and disposition: the contextual development of human values. Social Forces, 91(4), 1499-1528.

Maoz, Z., \& Henderson, E. A. (2013). The world religion dataset, 1945-2010: logic, estimates, and trends. International Interactions, 39(3), 265-291.

McCrae, R. R., \& Costa, P. T. (2008). Empirical and theoretical status of the five-factor model of personality traits. The SAGE handbook of personality theory and assessment, 1, 273-294.

Minns, C., \& Rizov, M. (2005). The spirit of capitalism? Ethnicity, religion, and self-employment in early 20 th century Canada. Explorations in Economic History, 42(2), 259-281.

Nair, K. R. G., \& Pandey, A. (2006). Characteristics of entrepreneurs: an empirical analysis. Journal of Entrepreneurship, 15(1), 47-61.

Nikolova, E., \& Simroth, D. (2015). Religious diversity and entrepreneurship in transition: lessons for policymakers. IZA Journal of European Labor Studies, 4(5), 1-21.

Norris, P., \& Inglehart, R. (2004). Sacred and secular: religion and politics worldwide. Cambridge, New York: Cambridge University Press.

North, D. C. (1991). Institutions. Journal of Economic Perspectives, 5(1), 97-112.

Noseleit, F. (2010). The entrepreneurial culture: guiding principles of the self-employed. In A. Freytag \& A. R. Thurik (Eds.), Entrepreneurship and culture (pp. 41-54). Berlin, Heidelberg: Springer-Verlag.

Nunziata, L., \& Rocco, L. (2011). The implications of cultural background on labour market choices: the case of religion and entrepreneurship. Institute for the Study of Labor Discussion Paper series, 6114.

Office for National Statistics. (2009, July 9). Final recommended questions for the 2011 census in England and Wales: Religion. Retrieved from https://www.ons.gov. uk/census/2011census/howourcensusworks/howweplanned the2011census/questionnairedevelopment/finalisingthe2011 questionnaire

Parks-Leduc, L., Feldman, G., \& Bardi, A. (2015). Personality traits and personal values: a meta-analysis. Personality and Social Psychology Review, 19(1), 3-29.

Parker, S. C. (2009). The economics of entrepreneurship. Cambridge, New York: Cambridge University Press.

Pew Research Center (2018, October 29). Eastern and western Europeans differ on importance of religion, views of minorities, and key social issues. Retrieved from https://www. pewforum.org/2018/10/29/eastern-and-western-europeansdiffer-on-importance-of-religion-views-of-minorities-andkey-social-issues/.

Rauch, A., \& Frese, M. (2007). Let's put the person back into entrepreneurship research: a meta-analysis on the relationship between business owners' personality traits, business creation, and success. European Journal of Work and Organizational Psychology, 16(4), 353-385. 
Rietveld, C. A., \& Van Burg, E. (2014). Religious beliefs and entrepreneurship among Dutch protestants. International Journal of Entrepreneurship and Small Business, 23(3), 279-295.

Roccas, S. (2005). Religion and value systems. Journal of Social Issues, 61(4), 747-759.

Roccas, S., \& Schwartz, S. H. (1997). Church-state relations and the association of religiosity with values: a study of Catholics in six countries. Cross-Cultural Research, 31(4), 356-375.

Rokeach, M. (1969). Value systems in religion. Review of Religious Research, 11(1), 3-23.

Saroglou, V., Delpierre, V., \& Dernelle, R. (2004). Values and religiosity: a meta-analysis of studies using Schwartz's model. Personality and Individual Differences, 37(4), 721-734.

Saroglou, V., Corneille, O., \& Van Cappellen, P. (2009). "Speak, Lord, your servant is listening": religious priming activates submissive thoughts and behaviors. The International Journal for the Psychology of Religion, 19(3), 143-154.

Schumpeter, J. A. (1934). The theory of economic development. Cambridge, Massachussets: Harvard University Press.

Schwartz, S. H. (1992). Universals in the content and structure of values: theoretical advances and empirical tests in 20 countries. Advances in Experimental Social Psychology, 25(1), 165.

Schwartz, S. H. (1994). Are there universal aspects in the structure and contents of human values? Journal of Social Issues, 50(4), 19-45.

Schwartz, S. H. (2001). European Social Survey core questionnaire development - chapter 7: a proposal for measuring value orientations across nations. London: European Social Survey, City University London Retrieved from: http://www. europeansocialsurvey.org/docs/methodology/core_ess_ questionnaire/ESS_core_questionnaire_human_values.pdf.

Schwartz, S. H. (2012). An overview of the Schwartz theory of basic values. Online Readings in Psychology and Culture, 2(1), 11.

Schwartz, S. H., \& Huismans, S. (1995). Value priorities and religiosity in four western religions. Social Psychology Quarterly, 58(2), 88-107.

Schwartz, S. H., \& Sagie, G. (2000). Value consensus and importance: a cross-national study. Journal of Cross-cultural Psychology, 31(4), 465-497.
Shane, S., \& Venkataraman, S. (2000). The promise of entrepreneurship as a field of research. Academy of Management Review, 25(1), 217-226.

Shariff, A. F., \& Norenzayan, A. (2007). God is watching you: priming God concepts increases prosocial behavior in an anonymous economic game. Psychological Science, 18(9), 803-809.

Tajfel, H., \& Turner, J. C. (1986). The social identity theory of intergroup behaviour. In S. Worchel \& W. G. Austin (Eds.), Psychology of intergroup relations (2nd ed., pp. 7-24). Chicago, Illinois: Nelson-Hall.

Tracey, P. (2012). Religion and organization: a critical review of current trends and future directions. Academy of Management Annals, 6(1), 87-134.

Van Praag, C. M., \& Versloot, P. H. (2007). What is the value of entrepreneurship? A review of recent research. Small Business Economics, 29(4), 351-382.

Verheul, I., Van Stel, A., \& Thurik, A. R. (2006). Explaining female and male entrepreneurship at the country level. Entrepreneurship and Regional Development, 18(2), 151183.

Weber, M. (1930). The Protestant ethic and the spirit of capitalism, tr. T. Parsons, London: Allen Unwin.

Wennekers, S., \& Thurik, A. R. (1999). Linking entrepreneurship and economic growth. Small Business Economics, 13(1), 2756.

Williamson, O. E. (2000). The new institutional economics: taking stock, looking ahead. Journal of Economic Literature, 38(3), 595-613.

Wyrwich, M. (2018). The effect of being Protestant on entrepreneurial choice. Jena Economic Research Papers, 2018-010. Retrieved from: https://www.econstor.eu/bitstream/10419 /194234/1/1029880980.pdf.

Zelekha, Y., Avnimelech, G., \& Sharabi, E. (2014). Religious institutions and entrepreneurship. Small Business Economics, 42(4), 747-767.

Publisher's note Springer Nature remains neutral with regard to jurisdictional claims in published maps and institutional affiliations. 